\title{
BREWING ON AN INDUSTRIAL AND A CRAFT SCALE - IMPACT ON THE PHYSICOCHEMICAL PROPERTIES AND VOLATILE COMPOUNDS PROFILE OF THE PALE PILSENER-STYLE LAGER BEER ANALYSED WITH HS/GC-MS
}

\author{
Kamil Królak* \\ Research and Innovation Centre Pro-Akademia \\ 9/11 Innowacyjna Str., 95-050 Konstantynow Łodzki, kamil.krolak@proakademia.eu \\ https://orcid.org/0000-0003-3295-0935 \\ Maria Buła \\ Research and Innovation Centre Pro-Akademia \\ 9/11 Innowacyjna Str., 95-050 Konstantynow Łodzki, maria.bula@proakademia.eu \\ https://orcid.org/0000-0002-2490-0201
}

Article history: Received 2 September 2021, Accepted 6 September 2021, Available online 7 September 2021

\begin{abstract}
Highlight
Volatile compounds profile of a craft and industrial beer analysed using headspace gas chromatography-mass spectrometry method.
\end{abstract}

\begin{abstract}
The pale Pilsener-style lager beers produced on a massive and craft scale were taken to analyse their basic physicochemical properties (alcohol content, $\mathrm{pH}$, haze, real degree of fermentation) and volatile compounds profiles. The research was carried out using a beer analyser equipment and a headspace gas chromatographymass spectrometry method (HS/GC-MS). The findings showed that in terms of physicochemical and flavour attributes, the quality of craft beers differed to a higher degree from the standard Pilsener beer quality than in the case of industrial beers.
\end{abstract}

\section{Keywords}

Industrial and craft beer; pilsener; volatile compounds; off-flavours; HS/GC-MS, physicochemical properties

\section{Introduction}

It is believed that the process of making beer represents the world's oldest biotechnology, which helps to account for the fact that the brewing industry is currently the most established on the alcoholic beverages market with beer being nearly the most consumed beverage in the world [1,2]. In generic terms, there are two main types of beer being produced both on an industrial and a craft (artisanal) scale, namely (1) ale - top fermenting styles of beer and (2) lager - bottom fermenting styles of beer, which refers to the type of yeast used in the fermentation process. Although the craft beer industry in Poland, as distinct from the industrial one, is primarily focused on producing ale beers rather than lagers, it is the production of the bottom fermenting style that has been found to grow faster recently (c. 3.5-fold faster than ale craft beers in 2019) [3]. Overall, there are three to five main commercial companies brewing on an industrial scale in Poland, being distinguished by the annual beer production exceeding $200000 \mathrm{hL}$, with their combined market share reaching 98\%, and these are particularly: Kompania Piwowarska, Grupa Żywiec and Carlsberg Polska [2,4]. Throughout the years, the prime objective of such large industrial breweries has been aimed at providing highly standardised product, designated "for everybody", so that the producers can meet the demands of the average consumer and at the same time maximise their profits $[5,6]$. As a consequence of this policy, the pale pilsener type of lager beer due to its mild and generally not very characteristic flavours has become ubiquitous on the market and is considered now the most dominant and widely brewed single beer style all over the world [7]. Nevertheless, as the noticeable change in consumer attitudes and preferences towards beer did occur in Poland in the beginning of the second decade of the 21st century, the number of microbreweries (craft breweries, contract breweries and brew pubs), offering products with enhanced sensory characteristics or new beer styles whatsoever, have been steadily increasing ever since then (it passed from 107 to 308 in the years 2010-2015) $[4,7,8]$. This phenomenon associated with opposition to standardisation of beer brewing and beer consumption is called "the craft beer revolution" [5,9]. Despite the popularity of this slogan and craft breweries in themselves among beer consumers in Poland these days, it has to be pointed out that there is no official, common shared 
and agreed definition of craft beer and craft breweries as well. It is of note, however, that there are many regional and national brewers associations all over the world, which represent independent microbreweries and simultaneously supply us with some working definitions in terms of craft brewing striving to safeguard their member's interest $[8,10]$. As far as Poland is concerned, it seems reasonable to invoke PSBR ("Polskie Stowarzyszenie Browarów Rzemieślniczych"), since according to its 2019 annual report, this microbrewers association was incorporating $25 \mathrm{craft}$ breweries throughout the country at the time, with their combined beer production volume making up to $50 \%$ of the total production volume of craft beer in Poland [3]. Although PSBR's regulations as to what craft brewery is do not strictly refer to brewery's annual production, it is declared that for all of the associated breweries it does not exceed $18000 \mathrm{hL}$. Apart from that, according to PSBR, a craft brewery is innovative as well as economically and personally independent of another (not artisanal) brewery. Moreover, it essentially uses traditional raw materials, i.e. water, barley malt, yeast and hops and thus theoretically provides a high-quality product being sold at a relatively high price [10].

\section{Brewing on an industrial and a craft scale}

Concerning the scale of production, the quality of even the same style of beer made following industrial and artisanal manufacturing methods might vary significantly, which opens up discussions which scale is favourable for providing better quality of beer [11]. In fact, one of the reasons for the change in consumer preferences for beer in favour of craft was the desire for new taste experiences provided by particular flavours, which were not being found in industrial beers [8]. On the other hand, in contrast to common belief, craft beer may turn out to be of inferior quality to industrial one due to the lack of such steps of production as pasteurisation and filtration processes as well as poor quality control in the production chain. The exclusion of microfiltration phase prior to, and heating-process after beer bottling may result in generating undesirable flavours induced by incompletely removed yeast and microbial contamination respectively [11]. Further, the ability of a small brewery to follow the quality of semi-finished product and contents of various beer compounds, and thus to maintain a steady production is limited because of small budget and resultant lack of investment in accurate analytical instruments like those based on chromatographic analysis, being vital for brewery's development and competition [12]. For apparently this reason, the SWOT analysis made by Wojtyra and Grudzień characterises the difficulty in providing consistently high-quality of beer as one of the weaknesses of the craft beer industry in Poland [4]. It is worth mentioning on an industrial beer, however, that in order to minimise production costs it is common nowadays for macrobreweries to brew with unmalted cereals (barley, maize, wheat or rice) as partial substitution of barley malt, which is by no means irrelevant for the quality and can have potentially negative effects on beer foam or flavour, for instance [11]. In fact, it is the latter that is considered of the greatest importance with regard to the sensory profile of the beer, and consequently beer's subsequent market performance $[1,2]$.

\section{Volatile compounds}

Beer flavour is contingent on presence and intensity of positive and negative taste and aroma characteristics, the latter being determined by many classes of volatile compounds derived from raw materials [2]. Furthermore, the ultimate volatile compounds profile of the beer is influenced by the production technologies (e.g. pasteurisation, microfiltration) and process conditions (wort aeration level, fermentation temperature, conditioning time), yeast strain (secondary metabolites), as well as storage conditions (light and oxygen contribution) and last but not least by microbial contamination [1,11-14]. Hence, In order to provide a highquality product, it is necessary to keep good manufacturing practice (GMP) and obtain the balance of the beer aroma through maintaining a proper concentration of volatiles such as esters, higher alcohols, carbonyl compounds (aldehydes and ketones), sulphur compounds and organic acids, which at concentrations above their sensory thresholds are perceived either detrimental or beneficial to beer flavour depending on its style $[4,14]$. In this way, the volatile profile is one of the unique characteristics of each beer style, determining its quality [15]. Pilsener, also commonly known as pils, represents the group of lager beers, which are generally brewed with the use of pale barley malts and fermented in relatively low temperatures $\left(6-12^{\circ} \mathrm{C}\right)$ by bottomfermenting yeast Saccharomyces pastorianus. Despite the fact that there are many variants of pilseners on the market throughout the world, which might stem from slight differentiation in choice of raw materials and methods of production, it is preferred that this style of beer be characterised by clean, crisp and refreshing hoppy taste, delicate fruity aroma, lean body (well attenuated beer), as well as clarity and colour intensity at the level of: $0-1$ and $4-8^{\circ} E B C$ respectively [16]. As opposed to the top-fermented beers, the volatile profile of the bottom-fermented ones is highlighted by aldehydes and ketones, rather than by esters and higher alcohols and this, by all means accounts for less intense taste sensations when consuming beers of pilsener style [17]. 
It is of note, however, that all of the abovementioned volatiles should be subject to control in order to obtain a clean flavour profile of the pilsener beer, since not only esters introducing fruity aromas and higher alcohols causing harshness negatively affect the flavour of lager, but also carbonyl compounds, i.e. aldehydes (acetaldehyde) and vicinal diketones (diacetyl) due to their very low sensory thresholds induce off-flavours such as grassy and buttery ones respectively [18]. Amongst other volatiles determining the quality of the pilsener beer, the sulphur compounds such as dimethyl sulphide (DMS) or methanethiol (methyl mercaptan) play a significant role, introducing at high concentrations unpleasant notes of cooked or rotten vegetables (e.g. maize, cabbage) [19]. According to the literature, however, subthreshold-levels of DMS (c. $30 \mu \mathrm{g} / \mathrm{L}$ ) or even slightly higher concentrations, below $100 \mu \mathrm{g} / \mathrm{L}$, are considered acceptable and beneficial to the flavour of lager [20,21].

\section{Gas chromatography}

Given the fact that beer volatile organic compounds (VOCs) are present in beer at relatively very low concentrations (from ng to $\mathrm{mg} \mathrm{L}^{-1}$ ), the need for accurate analyses of VOCs with the use of sensitive and modern techniques becomes apparent $[12,19]$. One of the most suitable and sophisticated analytical systems designed for both qualitative and quantitative analysis of extracted VOCs from beer is based on headspace gas chromatographic method coupled to mass spectrometry (HS/GC-MS). In generic terms, the identification is done by partitioning followed by MS (Mass Spectrometry) detection of analytes, being initially carried through a very thin capillary column by helium or another inert gas such as nitrogen or hydrogen, which is in contact with a stationary phase, i.e. an absorbent (e.g. porous polymers) covering the inner side of the column. Owing to different affinities of analytes to the stationary phase, the retention times will also be diverse, making it possible to identify individual compounds [12,19,22-24] (Figure 1). For more details on investment calculations with regard to GC-MS, especially meant for a craft brewery, refer to the source [12].

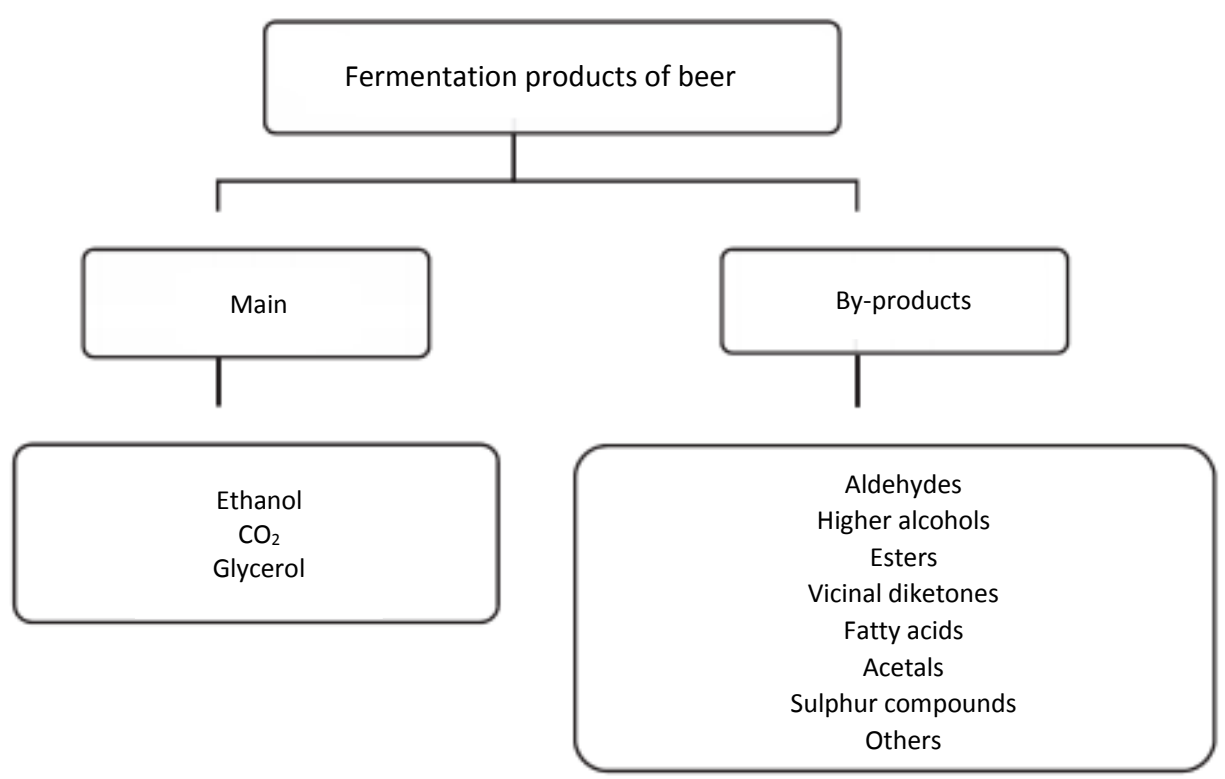

Figure 1. Ingredients of beer produced during fermentation and maturation. Source: The author's own modification on the basis of Kucharczyk et. al (2017) [22].

\section{Research purpose}

The aim of this study was to examine the volatile compounds profiles of craft and industrial (commercial) beers of pale Pilsener-style by the use of HS/GC-MS, with respect to beers' flavour attributes developed following industrial and artisanal manufacturing methods, along with pointing out potentially resulting quality defects. Given a significant contribution of volatiles to beer sensory characteristics and concomitantly consumer acceptance, as well as the influence of different manufacturing practises on the issue, studies might be useful for brewers in terms of identification the reasons for off-flavours, showing the need for both having at their disposal of sophisticated analytical instruments and maintaining high-quality production standards at each stages of brewing, so that consumers can be supplied with beers of appropriate flavour character for specific style. Further, the physicochemical characterisation of beers will enable to determine if the basic beer parameters, as alcohol content, are in accordance with these specific properties included on the labels, as well as the analysis 
of other physicochemical attributes like beer haze or colour intensity will provide a better insight into the impact of the manufacturing scale on the quality of beer. Those results along with determined volatile compounds profiles of beers might also be of particular interest to consumers.

\section{Methods}

Materials

A total of 12 Pilsener-style lager beers produced on a craft ( 6 beers - group I: A-F) and a massive (6 beers group II: G-L) scale in Poland were collected for the study. The beers were purchased from the supermarkets or specialised craft beer shops, depending on their availability. The samples of commercial (industrial) beers were selected amongst beers being produced by the largest beer companies in Poland according to the literature [4]. Craft beer samples were chosen based on the affiliation of a brewery to one of the biggest Polish microbrewers association (PSBR). Beers produced by such brewery are distinguished by having the legally protected mark with the information „craft beer” claimed on their label.

\section{Analysis of volatile compounds through HS/GC-MS}

The analysis of volatile compounds from the hypersurface phase of the tested beers was carried out using the gas chromatography technique coupled with mass spectrometry and headspace attachment (HS-GC-MS). Beer samples with a volume of $10 \mathrm{ml}$ were placed in a glass vial with a capacity of $20 \mathrm{ml}$ containing approx. $4 \mathrm{~g}$ of sodium chloride. The vial was then closed tightly with an aluminium cap with silicone/PTFE sept. After mixing, sample was analysed using the Agilent 7820A gas chromatograph, the Agilent 5977B GC/MSD mass detector (mass spectrometer) and the 7697A Agilent headspace phase sample feeder. The separation was made on a Restek Rtx-5 column with a length of $60 \mathrm{~m}$, a diameter of $0.32 \mathrm{~mm}$ and a film thickness of $1 \mu \mathrm{m}$. Helium was used as a carrier gas and the flow rate was $1.1 \mathrm{ml} / \mathrm{min}$. The temperature of the ion source was $230^{\circ} \mathrm{C}$ and the quadrupole was $150^{\circ} \mathrm{C}$, ionisation energy was $70 \mathrm{eV}$. Mass acquisition mode in the range of masses 20400. The identification of individual compounds was based on a comparison of the spectrum with that available in the NIST library. The content of dimethyl sulphide (DMS) and 2,3-butanedione was also measured by quantitatively comparing its retention time with the retention time of the standard for which the calibration curve was prepared. Each sample was analysed in 3 repetitions. Identification of volatiles was verified using linear retention indices (LRI) - calculated and found in the literature [25-29]. In gas chromatography method, the area of a peak generated is proportional to the amount of the compound that is present in the sample. The volatile compounds profile of the analysed samples was defined as the percentage of the surface area under the peak of a specific compound in relation to the sum of the surface areas of all identified compounds on the chromatogram.

\section{Physicochemical analysis of beer}

The basic physicochemical properties of commercial and craft beers were tested with the beer analyser equipment. The DMA 4500 M (Anton-Paar) density measuring instrument combined with the Alcolyzer Beer ME and Turbidity meter Haze QC ME modules were used for determination of beer's: density $\left(\mathrm{g} / \mathrm{cm}^{3}\right)$, alcohol content $(\% \mathrm{v} / \mathrm{v})$, original and final extract ( $\left.{ }^{\circ} \mathrm{Plato}\right)$, real degree of fermentation (RDF\%), haze $\left({ }^{\circ} \mathrm{EBC}\right)$, colour intensity $\left({ }^{\circ} \mathrm{EBC}\right)$ and $\mathrm{pH}$. All the measurements were performed in triplicate, by injection into the Beer Analyzer $50 \mathrm{~mL}$ of each sample previously decarbonated by the use of laboratory shaker.

\section{Statistical analysis}

Data collected from triplicate beer samples were subjected to statistical analysis using the STATISTICA 13 (Dell, StatSoft) [30]. In order to compare values, one-way analysis of variance (ANOVA) and Tukey HSD at significance level of $\alpha=0.05$ was performed.

\section{Results and discussion}

\section{Physicochemical characterisation}

The most important physicochemical properties of examined beers are shown in Table 1. Statistically significant differences with respect to all measured parameters between the group of craft (group I: A-F) and the group of industrial (group II: G-L) beers were observed $(P<0.05)$ (Figure 2: a-g). These parameters influence beer sensory quality as well as its microbiological stability. 
Table 1. Physicochemical properties of examined beers. Source: Results of the authors' research.

\begin{tabular}{|c|c|c|c|c|c|c|c|c|c|c|c|c|}
\hline \multirow{3}{*}{ Parameter } & \multicolumn{12}{|l|}{ Sample } \\
\hline & \multicolumn{6}{|c|}{ Group I-craft beers } & \multicolumn{6}{|c|}{ Group II - industrial beers } \\
\hline & A & B & c & D & E & $\mathbf{F}$ & G & H & 1 & J & K & L \\
\hline $\begin{array}{l}\text { Alcohol content } \\
(\% \mathrm{v} / \mathrm{v})\end{array}$ & $3.99 \pm 0.01^{\mathrm{h}}$ & $5.38 \pm 0.01^{b}$ & $5.34 \pm 0.05^{b c}$ & $5.04 \pm 0.04 e^{e}$ & $4.93 \pm 0.04^{\mathrm{ef}}$ & $3.90 \pm 0.01^{h}$ & $4.83 \pm 0.01^{\mathrm{fg}}$ & $4.78 \pm 0.11^{\mathrm{g}}$ & $5.24 \pm 0.02^{c d}$ & $5.42 \pm 0.04^{\mathrm{ab}}$ & $5.53 \pm 0.02^{\mathrm{a}}$ & $5.20 \pm 0.01^{d}$ \\
\hline Final extract $\left({ }^{\circ} \mathrm{P}\right)$ & $2.51 \pm 0.01^{c}$ & $1.78 \pm 0.01^{b}$ & $1.97 \pm 0.03^{e}$ & $2.26 \pm 0.02^{\mathrm{d}}$ & $2.54 \pm 0.02^{c}$ & $2.71 \pm 0.00^{\mathrm{a}}$ & $2.63 \pm 0.01^{b}$ & $1.48 \pm 0.04 i$ & $1.72 \pm 0.02^{\mathrm{g}}$ & $1.51 \pm 0.01^{\mathrm{hi}}$ & $0.82 \pm 0.01^{j}$ & $1.54 \pm 0.01^{h}$ \\
\hline $\begin{array}{l}\text { Colour intensity } \\
\left({ }^{\circ} E B C\right)\end{array}$ & $8.43 \pm 0.02^{j}$ & $13.63 \pm 0.05^{c}$ & $15.13 \pm 0.16^{b}$ & $12.30 \pm 0.12^{d}$ & $11.05 \pm 0.02^{f}$ & $17.32 \pm 0.06^{a}$ & $11.88 \pm 0.01^{e}$ & $7.95 \pm 0.03^{k}$ & $9.03 \pm 0.01^{i}$ & $10.51 \pm 0.048$ & $9.84 \pm 0.01^{\mathrm{h}}$ & $7.08 \pm 0.01$ \\
\hline Haze ('EBC) & $1.06 \pm 0.02^{\mathrm{ef}}$ & $1.35 \pm 0.01^{e}$ & $10.35 \pm 0.58^{a}$ & $6.65 \pm 0.21^{b}$ & $2.95 \pm 0.08^{\mathrm{d}}$ & $5.64 \pm 0.03^{c}$ & $0.79 \pm 0.01^{\mathrm{fg}}$ & $0.24 \pm 0.02^{\mathrm{h}}$ & $0.38 \pm 0.01^{\mathrm{gh}}$ & $0.39 \pm 0.02^{\mathrm{gh}}$ & $0.53 \pm 0.02^{\mathrm{gh}}$ & $0.38 \pm 0.03^{\mathrm{gh}}$ \\
\hline $\begin{array}{l}\text { Original extract } \\
\left({ }^{\circ} \mathrm{P}\right)\end{array}$ & $10.09 \pm 0.01^{\mathrm{g}}$ & $11.92 \pm 0.02^{\mathrm{ab}}$ & $12.02 \pm 0.06^{a}$ & $11.75 \pm 0.07^{\mathrm{bcd}}$ & $11.82 \pm 0.06^{\mathrm{bc}}$ & $10.11 \pm 0.01^{\mathrm{g}}$ & $11.72 \pm 0.02^{\text {cd }}$ & $10.56 \pm 0.15^{f}$ & $11.61 \pm 0.02^{d}$ & $11.74 \pm 0.07^{c d}$ & $11.30 \pm 0.03^{e}$ & $11.38 \pm 0.01^{e}$ \\
\hline $\mathrm{pH}$ & $4.53 \pm 0.01^{a}$ & $5.23 \pm 0.00^{\mathrm{a}}$ & $4.80 \pm 0.01^{b}$ & $4.65 \pm 0.01^{d}$ & $4.61 \pm 0.00^{e}$ & $4.57 \pm 0.00^{f}$ & $4.79 \pm 0.00^{b}$ & $4.27 \pm 0.00^{j}$ & $4.72 \pm 0.01^{c}$ & $4.57 \pm 0.01^{f}$ & $4.42 \pm 0.00^{\circ}$ & $4.45 \pm 0.01^{\mathrm{h}}$ \\
\hline DMS $(\mu \mathrm{g} / \mathrm{l})$ & $54.40 \pm 6.23^{\mathrm{bc}}$ & $65.61 \pm 5.37^{b}$ & $136.29 \pm 20.18^{\mathrm{a}}$ & $137.49 \pm 13.66^{a}$ & $43.15 \pm 4.04^{\mathrm{bcd}}$ & $0.00 \pm 0.00^{d}$ & $37.80 \pm 32.73^{\mathrm{cd}}$ & $38.15 \pm 33.07 \mathrm{bcd}$ & $0.00 \pm 0.00^{d}$ & $0.00 \pm 0.00^{d}$ & $0.00 \pm 0.00^{d}$ & $0.00 \pm 0.00^{d}$ \\
\hline Density $(\mathrm{g} / \mathrm{cm} 3)$ & $1.0080 \pm 0.00^{c}$ & $1.0051 \pm 0.00^{f}$ & $1.0058 \pm 0.00^{e}$ & $1.0070 \pm 0.00^{d}$ & $1.0081 \pm 0.00^{c}$ & $1.0088 \pm 0.00^{\mathrm{a}}$ & $1.0084 \pm 0.00^{\mathrm{b}}$ & $1.0039 \pm 0.00^{i}$ & $1.0048 \pm 0.00 \mathrm{~g}$ & $1.0040 \pm 0.00^{\mathrm{hi}}$ & $1.0014 \pm 0.00^{j}$ & $1.0042 \pm 0.00^{\mathrm{h}}$ \\
\hline $\begin{array}{l}\text { Real degree of } \\
\text { fermentation } \\
\text { (RDF\%) }\end{array}$ & $60.60 \pm 0.06^{i}$ & $68.71 \pm 0.05^{d}$ & $67.58 \pm 0.27 e$ & $65.25 \pm 0.16^{f}$ & $63.639 \pm 0.1^{8}$ & $59.05 \pm 0.04$ & $62.64 \pm 0.06^{h}$ & $69.48 \pm 0.49^{c}$ & $68.86 \pm 0.11^{d}$ & $70.46 \pm 0.04^{b}$ & $75.00 \pm 0.07^{a}$ & $69.89 \pm 0.05^{c}$ \\
\hline
\end{tabular}

letters (a-l) within the same line (horizontally) differ significantly with a p value $<0.05$ 

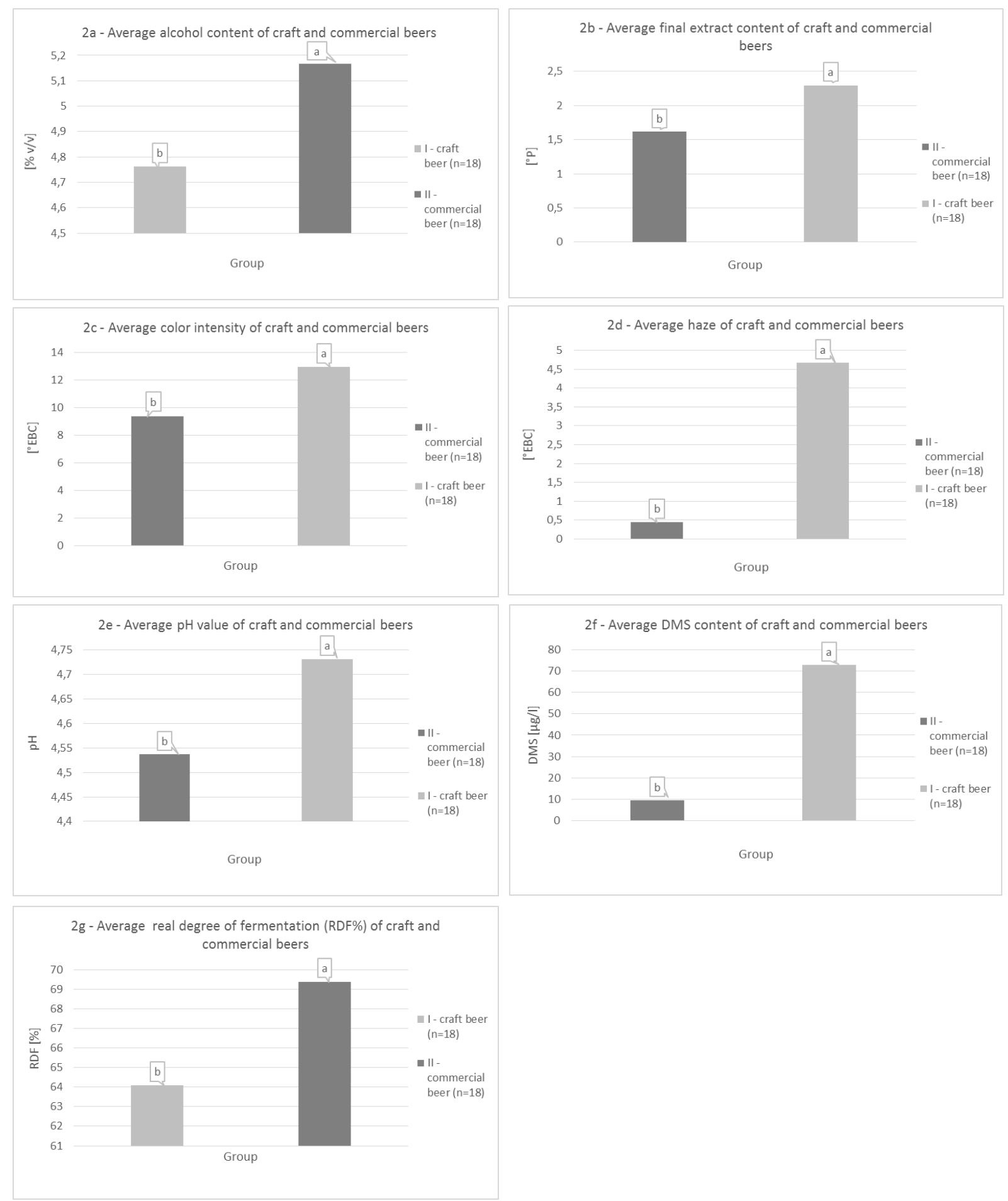

Figure $2(a, b, c, d, e, f, g)$. Statistically significant differences between craft (I) and commercial (II) group of beer. Source: Results of the authors' research.

Sensory evaluation of beer covers four different aspects such as beer's appearance, aroma, flavour, and mouthfeel [31]. The assessment of beer's appearance incorporates, amongst others, colour intensity and clarity, which both significantly affect hedonic response, while drinking beer. If the expectation and the visual experience during drinking differ, then beer quality may be rated negatively right from the beginning [32]. In this way, regardless of the manufacturing scale, it is generally best to produce beer with appearance attributes that match the typical characteristics of a specific beer style. According to the literature, lager beer (principally 
the pale Pilsener-style) is usually expected to not exceed $1^{\circ} \mathrm{EBC}$ haze, which is considered a brilliant (clear) beer [33]. In the twelve beers studied, haze values were in the range of 0.24 to $10.35^{\circ} \mathrm{EBC}$ (Table 1 ). Thus, a considerable variation in beer haze among samples was observed. It is of note that only beers made by industrial processes were characterised by a desirable haze for lager beer, i.e. $<1^{\circ} \mathrm{EBC}\left(0.45^{\circ} \mathrm{EBC}\right.$ on average), while all craft beer samples exhibited higher values ( $4.67^{\circ} \mathrm{EBC}$ on average) (Table 1 and Figure $\left.2 \mathrm{~d}\right)$. The formation of haze is influenced by a lot of factors, including raw materials used in the process as well as mash, wort and beer production technology [34]. Craft beers, as opposed to industrial beers, are usually made without the addition of chemical adsorbents removing haze-active compounds during filtration (proteins and polyphenols) such as PVPP or silica gel, or by completely eliminating the process of beer filtration. It is probably the main cause of increased haze values measured in craft beers in comparison to beers brewed on an industrial scale. Similarly, colour intensity measured was also significantly higher among craft beers than among industrial beers (Figure 2c) $(P<0.05)$. In the Doorn et. at. (2019) study it was confirmed that, as the colour intensity of beer increased its rated ability to quench one's thirst decreased [32]. Given that thirst-quenching quality of Pilsener-style lager beer is of great importance to consumers due to their wish to drink refreshing beer, it should be concluded that industrial beers in terms of colour intensity are of superior quality to craft ones. On the other hand, only two out of six commercial beers (samples $\mathrm{H}$ and $\mathrm{L}$ ) had a colour of proper intensity for pilsener style, i.e. in the range of 4$8^{\circ} \mathrm{EBC}$ (Table 1) [16]. In contrast to parameters of beer haze and colour intensity, the average real degree of fermentation (RDF), and thus also the average alcohol content were significantly lower for the group of craft beers than for the group of industrial beers $(P<0.05)$ (Figure $2 \mathrm{a}, 2 \mathrm{~g})$. RDF determines the rate of real attenuation, that is the actual percentage of sugars consumed by yeast and converted into alcohol and carbon dioxide during the fermentation process. Hence from a sensory point of view, that parameter influence the textural attributes (so-called mouthfeel), as a lower RDF percentage gives rise to beers with higher levels of sweetness and syrupy taste, whereas the higher RDF\%, the more refreshing, lighter and drier the beer [35]. Andrade et al. (2016) [36], when evaluating the quality of different brands of Pilsner-style beer, reported RDF between 59.02 and $69.44 \%$. Overall our findings regarding RDF\% are in accordance with findings reported by Andrade et al., except for four samples of industrial beers, namely $\mathrm{H}, \mathrm{J}, \mathrm{K}$ and L, which exhibited higher RDF\% (Table 1 ). It has to be pointed out, however, that sugar syrups were used as malt adjuncts (partial substitutes of barley malt) when producing $\mathrm{K}$ and $L$ beers, which significantly increased the content of easily fermented sugars in worts, hence also RDF\% (information with respect to raw materials composition was claimed on the label). The labelling of beers must also indicate the alcoholic strength by volume. Considering that the tolerance allowed in terms of the indication of the alcoholic strength by volume for beers featuring alcoholic content below $5.5 \% \mathrm{v} / \mathrm{v}$ is $0.5 \% \mathrm{v} / \mathrm{v}$ [37], only three samples (two industrial beers - I and J, and one craft beer - B) fell short of that specific requirement (table 2). Tozetto et al. (2019) [38] when analysing 28 Pilsener-style lager beers, reported average alcohol content at the level of $4.7 \% \mathrm{v} / \mathrm{v}$, which is more consistent with the results obtained for the group of craft beers $(4.75 \%$ $\mathrm{v} / \mathrm{v}$ on average) than for the group of industrial beers $(5.15 \% \mathrm{v} / \mathrm{v}$ on average) (Figure $2 \mathrm{a})$ ). The $\mathrm{pH}$ of the beers studied was in the range of 4.27-5.23. It is generally stated that lager beer should be characterised by a $\mathrm{pH}$ of around 4.0-5.0. Sample B of craft beer had the highest (5.23), whereas sample H of industrial beer the lowest $\mathrm{pH}$ (4.27) (Table 1). Also the average $\mathrm{pH}$ of craft beers was significantly higher than average $\mathrm{pH}$ of industrial beers (Figure 2e). To sum up, the results show that the manufacturing scale does seem to impact the physicochemical properties of the pale Pilsener-style lager beer. The average values of the basic characteristics of beers produced on a craft scale (by artisanal processes) deviates from standards for Pilsener-style beer to a higher degree than in the case of beers made following industrial processes. In this respect, from the point of view of the average consumer, industrial beers may be perceived of superior quality to craft beers.

\section{Volatile compounds identification}

The HS/GC-MS analysis of the pale Pilsener-style lager beers provided the information about volatile profile of each sample (Table 3), which paved the way for the characterisation of the flavours of individual beers as well as the comparison of the volatile compounds' profiles between the groups of industrial and craft beers. The analysis of volatile compounds in craft and industrial beers of Pilsener-style with the use of HS-SPME/GC-MS made by Giannetti et. al. (2019) [5] showed that manufacturing scale has a substantial impact on the beer volatile compounds profiles, as only 13 out of 111 volatiles identified were simultaneously present in all 79 beers analysed (42 craft and 37 industrial products purchased on the Italian market). Based on the evaluation of average concentrations, expressed as TIC area, 6 out of 13 identified compounds were subsequently assigned to the group of craft beers, whereas the rest of them to the group of industrial beers, giving the discrimination as to which group of beers was characterised by a higher content of an individual compound. The authors 
concluded their study with the encouragement for other scientists to further characterise quality marker compounds of craft beers, underlining the need for quantification of the identified markers by analysis of the pure standard. Therefore, in this study beers purchased on the Polish market were analysed in order to determine their volatile compounds profiles (qualitative analysis) with additional focus on quantitative analysis of dimethyl sulphide (DMS) and 2,3-butanedione (diacetyl), by using respective standards. These two volatile compounds are potentially present in beer and introduce, at high concentrations, unpleasant notes of cooked vegetables and butter respectively.

In the analysed batch of samples a total of 57 volatile compounds were identified by using NIST spectrum library and literature LRI values (Table 4). Those compounds can be classified into 6 groups, namely: esters (29), alcohols (14), carboxylic acids (3), carbonyl compounds (6), terpenes (4) and sulphur compounds (1). The volatile compounds profiles of 12 beers, 6 from craft group (A-F) and 6 from commercial group (G-L), are shown in Table 3. From the results, it is clear that the volatiles production was higher in the beers made by artisanal processes (especially in sample B) than in the industrial beers (Table 3). On average, the craft beers featured higher quantities of all identified compounds from 6 mentioned groups, for instance, an average of 14 esters and 7 alcohols were identified in the craft beers, whereas an average of 9 esters and 6 alcohols were identified in the industrial beers. These basic results are consistent with previous literature reports [11] and highlight just how standardisation procedures being implemented in commercial breweries (filtration and pasteurisation) as well as a better control of manufacturing processes in the case of industrial beers may contribute to a flattening or a complete elimination of a specific volatile compounds from the finished product. On the one hand, based on the results obtained it might be argued that craft beers retain more flavour attributes or nutritional properties, nevertheless, as far as the pale Pilsener-style lager beer is concerned, it must be stressed that too intense aromas disturb the clean profile desired for this style of beer and consequently negatively affect the beer quality.

Table 2. Comparison of alcohol content measured and labelled for studied beers. Source: Results of the authors' research.

\begin{tabular}{|c|c|c|c|c|c|c|c|c|c|c|c|c|}
\hline \multirow{3}{*}{ Parameters } & \multicolumn{12}{|c|}{ Sample } \\
\hline & \multicolumn{6}{|c|}{ Group I - craft beers } & \multicolumn{6}{|c|}{ Group II - industrial beers } \\
\hline & A & B & C & D & $\mathbf{E}$ & $\mathbf{F}$ & G & H & 1 & J & K & $\mathbf{L}$ \\
\hline $\begin{array}{l}\text { Alcohol content } \\
\text { measured }(\% \mathrm{v} / \mathrm{v})\end{array}$ & 3.99 & 5.38 & 5.34 & 5.04 & 4.93 & 3.90 & 4.83 & 4.78 & 5.24 & 5.42 & 5.53 & 5.20 \\
\hline $\begin{array}{l}\text { Alcohol content } \\
\text { labelled (\% v/v) }\end{array}$ & 4.40 & 4.70 & 5.00 & 5.00 & 4.80 & 4.10 & 5.00 & 5.00 & 6.00 & 6.00 & 5.70 & 5.50 \\
\hline$\left|\Delta_{\mathrm{A}}\right|$ & 0.41 & 0.68 & 0.34 & 0.04 & 0.13 & 0.20 & 0.17 & 0.22 & 0.76 & 0.58 & 0.17 & 0.30 \\
\hline
\end{tabular}

$\left|\Delta_{A}\right|$ - the absolute value of a difference between alcohol content measured and labelled for specific beer 
Table 3. Average volatiles profiles $(n=3)$ of 12 beers, 6 from commercial group and 6 from craft group. Source: Results of the authors' research

\begin{tabular}{|c|c|c|c|c|c|c|c|c|c|c|c|c|}
\hline \multirow{3}{*}{ Compound } & \multicolumn{12}{|l|}{ Sample } \\
\hline & \multicolumn{6}{|c|}{ Group I- craft beers } & \multicolumn{6}{|c|}{ Group II - industrial beers } \\
\hline & A & B & C & D & E & $F$ & G & H & 1 & J & K & L \\
\hline Acetaldehyde & $0.039 \pm 0.002^{f}$ & $0.063 \pm 0.002^{e}$ & $0.155 \pm 0.009^{b}$ & $0.129 \pm 0.003^{\text {cd }}$ & $0.109 \pm 0.004^{d}$ & $0.118 \pm 0.003^{\text {cd }}$ & $0.131 \pm 0.007^{c}$ & $0.109 \pm 0.002^{d}$ & $0.167 \pm 0.011^{b}$ & $0.258 \pm 0.017^{a}$ & $0.071 \pm 0.003^{e}$ & $0.160 \pm 0.002^{b}$ \\
\hline Ethanol & $86.881 \pm 0.455^{\mathrm{ab}}$ & $82.359 \pm 0.383^{d}$ & $84.730 \pm 0.781^{\circ}$ & $85.708 \pm 0.468^{\mathrm{bc}}$ & $87.367 \pm 0.185^{a}$ & $87.032 \pm 0.504^{\mathrm{ab}}$ & $86.971 \pm 0.499^{\mathrm{ab}}$ & $82.996 \pm 0.468^{d}$ & $86.081 \pm 0.614^{\text {abc }}$ & $85.711 \pm 0.536^{b c}$ & $82.949 \pm 0.242^{\mathrm{d}}$ & $87.206 \pm 0.175^{\mathrm{a}}$ \\
\hline Acetone & $0.000 \pm 0.000^{c}$ & $0.126 \pm 0.017^{\mathrm{a}}$ & $0.040 \pm 0.008^{b}$ & $0.101 \pm 0.021^{a}$ & $0.046 \pm 0.010^{b}$ & $0.000 \pm 0.000^{c}$ & $0.000 \pm 0.000^{c}$ & $0.000 \pm 0.000^{c}$ & $0.000 \pm 0.000^{c}$ & $0.000 \pm 0.000^{c}$ & $0.000 \pm 0.000^{c}$ & $0.000 \pm 0.000^{c}$ \\
\hline 2-Propanol & $0.000 \pm 0.000^{b}$ & $0.459 \pm 0.003^{\mathrm{a}}$ & $0.000 \pm 0.000^{b}$ & $0.000 \pm 0.000^{b}$ & $0.000 \pm 0.000^{b}$ & $0.000 \pm 0.000^{b}$ & $0.000 \pm 0.000^{b}$ & $0.000 \pm 0.000^{b}$ & $0.000 \pm 0.000^{b}$ & $0.000 \pm 0.000^{b}$ & $0.000 \pm 0.000^{b}$ & $0.000 \pm 0.000^{b}$ \\
\hline 2-Nitroethanol & $0.000 \pm 0.000^{\mathrm{a}}$ & $0.000 \pm 0.000^{\mathrm{a}}$ & $0.030 \pm 0.000^{a}$ & $0.000 \pm 0.000^{\mathrm{a}}$ & $0.000 \pm 0.000^{a}$ & $0.000 \pm 0.000^{\mathrm{a}}$ & $0.000 \pm 0.000^{\mathrm{a}}$ & $0.000 \pm 0.000^{\mathrm{a}}$ & $0.000 \pm 0.000^{2}$ & $0.000 \pm 0.000^{a}$ & $0.000 \pm 0.000^{\mathrm{a}}$ & $0.000 \pm 0.000^{\mathrm{a}}$ \\
\hline Ethyl formate & $0.000 \pm 0.000^{c}$ & $0.000 \pm 0.000^{c}$ & $0.029 \pm 0.004^{a}$ & $0.011 \pm 0.009^{b}$ & $0.000 \pm 0.000^{c}$ & $0.000 \pm 0.000^{c}$ & $0.000 \pm 0.000^{c}$ & $0.000 \pm 0.000^{c}$ & $0.000 \pm 0.000^{c}$ & $0.000 \pm 0.000^{c}$ & $0.000 \pm 0.000^{c}$ & $0.000 \pm 0.000^{c}$ \\
\hline Dimethyl sulphide & $0.025 \pm 0.003^{b}$ & $0.020 \pm 0.000^{b}$ & $0.047 \pm 0.005^{\mathrm{a}}$ & $0.049 \pm 0.004^{\mathrm{a}}$ & $0.015 \pm 0.002^{\mathrm{bc}}$ & $0.014 \pm 0.012^{\mathrm{bc}}$ & $0.007 \pm 0.012^{b c}$ & $0.012 \pm 0.011^{b c}$ & $0.000 \pm 0.000^{c}$ & $0.000 \pm 0.000^{c}$ & $0.000 \pm 0.000^{c}$ & $0.000 \pm 0.000^{c}$ \\
\hline 1-propanol & $0.348 \pm 0.005^{\mathrm{fg}}$ & $0.598 \pm 0.004^{c}$ & $0.308 \pm 0.001^{\mathrm{hi}}$ & $0.511 \pm 0.009^{d}$ & $0.365 \pm 0.020^{f}$ & $0.364 \pm 0.006^{f}$ & $0.336 \pm 0.005^{g h}$ & $1.398 \pm 0.018^{\mathrm{a}}$ & $0.410 \pm 0.011^{\mathrm{e}}$ & $0.538 \pm 0.004^{d}$ & $0.663 \pm 0.006^{b}$ & $0.300 \pm 0.002^{i}$ \\
\hline Acetic acid & $0.127 \pm 0.016^{\mathrm{a}}$ & $0.041 \pm 0.007^{\mathrm{ccd}}$ & $0.059 \pm 0.002^{b}$ & $0.107 \pm 0.011^{a}$ & $0.055 \pm 0.008^{\mathrm{bc}}$ & $0.129 \pm 0.026^{\mathrm{a}}$ & $0.031 \pm 0.003^{\mathrm{bcd}}$ & $0.045 \pm 0.006^{\mathrm{de}}$ & $0.023 \pm 0.003^{\mathrm{ae}}$ & $0.025 \pm 0.004^{\text {cde }}$ & $0.000 \pm 0.000^{\mathrm{e}}$ & $0.032 \pm 0.010^{\text {bcc }}$ \\
\hline Ethyl acetate & $2.960 \pm 0.146^{\text {ef }}$ & $4.168 \pm 0.122^{b}$ & $4.660 \pm 0.267^{\circ}$ & $3.260 \pm 0.113^{\mathrm{de}}$ & $3.035 \pm 0.088^{e^{f}}$ & $2.630 \pm 0.128^{f}$ & $3.757 \pm 0.220^{\mathrm{bc}}$ & $2.702 \pm 0.115^{t}$ & $3.2648 \pm 0.153^{\text {de }}$ & $2.775 \pm 0.171^{f}$ & $5.063 \pm 0.063^{a}$ & $3.477 \pm 0.052^{\text {cd }}$ \\
\hline Isobutanol & $0.826 \pm 0.007^{d}$ & $0.578 \pm 0.009^{f}$ & $0.823 \pm 0.030^{d}$ & $0.889 \pm 0.026^{\text {cd }}$ & $0.958 \pm 0.021^{\text {bc }}$ & $0.924 \pm 0.023^{c}$ & $0.717 \pm 0.010^{\mathrm{e}}$ & $1.401 \pm 0.032^{\mathrm{a}}$ & $1.002 \pm 0.045^{b}$ & $1.402 \pm 0.037^{\mathrm{a}}$ & $0.942 \pm 0.013^{\mathrm{bc}}$ & $0.828 \pm 0.008^{d}$ \\
\hline 3-Methyl-2-butanone & $0.000 \pm 0.000^{b}$ & $0.000 \pm 0.000^{b}$ & $0.000 \pm 0.000^{b}$ & $0.029 \pm 0.002^{\mathrm{a}}$ & $0.000 \pm 0.000^{6}$ & $0.000 \pm 0.000^{b}$ & $0.000 \pm 0.000^{b}$ & $0.000 \pm 0.000^{b}$ & $0.000 \pm 0.000^{b}$ & $0.000 \pm 0.000^{\mathrm{b}}$ & $0.000 \pm 0.000^{b}$ & $0.000 \pm 0.000^{b}$ \\
\hline 1-butanol & $0.000 \pm 0.000^{c}$ & $0.080 \pm 0.000^{\mathrm{b}}$ & $0.000 \pm 0.000^{\mathrm{c}}$ & $0.000 \pm 0.000^{c}$ & $0.000 \pm 0.000^{c}$ & $0.000 \pm 0.000^{c}$ & $0.000 \pm 0.000^{c}$ & $0.337 \pm 0.006^{\mathrm{a}}$ & $0.000 \pm 0.000^{c}$ & $0.000 \pm 0.000^{c}$ & $0.080 \pm 0.000^{b}$ & $0.000 \pm 0.000^{c}$ \\
\hline Methyl isobutyrate & $0.000 \pm 0.000^{b}$ & $0.067 \pm 0.006^{\mathrm{a}}$ & $0.000 \pm 0.000^{b}$ & $0.000 \pm 0.000^{\mathrm{b}}$ & $0.000 \pm 0.000^{b}$ & $0.000 \pm 0.000^{\mathrm{b}}$ & $0.000 \pm 0.000^{\mathrm{b}}$ & $0.000 \pm 0.000^{b}$ & $0.000 \pm 0.000^{b}$ & $0.000 \pm 0.000^{\mathrm{b}}$ & $0.000 \pm 0.000^{b}$ & $0.000 \pm 0.000^{\mathrm{b}}$ \\
\hline Ethyl propionate & $0.027 \pm 0.006^{\mathrm{de}}$ & $0.073 \pm 0.006^{b}$ & $0.027 \pm 0.006^{\mathrm{de}}$ & $0.037 \pm 0.006^{d}$ & $0.020 \pm 0.000^{\mathrm{e}}$ & $0.020 \pm 0.000^{e}$ & $0.040 \pm 0.000^{d}$ & $0.057 \pm 0.006^{c}$ & $0.080 \pm 0.010^{b}$ & $0.030 \pm 0.000^{\mathrm{de}}$ & $0.096 \pm 0.003^{\mathrm{a}}$ & $0.040 \pm 0.000^{d}$ \\
\hline Propyl acetate & $0.000 \pm 0.000^{b}$ & $0.000 \pm 0.000^{b}$ & $0.000 \pm 0.000^{\mathrm{b}}$ & $0.000 \pm 0.000^{b}$ & $0.000 \pm 0.000^{b}$ & $0.000 \pm 0.000^{b}$ & $0.000 \pm 0.000^{b}$ & $0.000 \pm 0.000^{b}$ & $0.000 \pm 0.000^{b}$ & $0.000 \pm 0.000^{\mathrm{b}}$ & $0.025 \pm 0.001^{\mathrm{a}}$ & $0.000 \pm 0.000^{\mathrm{b}}$ \\
\hline 1-Butanol. 3-methyl- & $4.773 \pm 0.041^{\mathrm{ef}^{\mathrm{f}}}$ & $5.715 \pm 0.045^{b}$ & $4.563 \pm 0.134^{\mathrm{fg}}$ & $5.080 \pm 0.118^{c d}$ & $4.494 \pm 0.057^{f \mathrm{~g}}$ & $5.168 \pm 0.119^{\mathrm{cd}}$ & $4.323 \pm 0.053^{g}$ & $6.405 \pm 0.128^{\mathrm{a}}$ & $4.947 \pm 0.166^{\mathrm{de}}$ & $5.317 \pm 0.128^{\mathrm{cd}}$ & $4.391 \pm 0.059^{8}$ & $3.940 \pm 0.036^{h}$ \\
\hline 1-Butanol. 2-methyl- & $1.770 \pm 0.024^{\text {def }}$ & $1.615 \pm 0.031^{f}$ & $1.706 \pm 0.075^{e f}$ & $1.885 \pm 0.054^{\text {cd }}$ & $2.038 \pm 0.037^{\mathrm{bc}}$ & $1.810 \pm 0.065^{\mathrm{de}}$ & $1.839 \pm 0.029^{\mathrm{de}}$ & $1.921 \pm 0.049^{\text {bcd }}$ & $2.046 \pm 0.096^{b}$ & $2.448 \pm 0.070^{a}$ & $1.778 \pm 0.040^{\mathrm{de}}$ & $1.694 \pm 0.030^{\text {ef }}$ \\
\hline 2-Pentanone. 4-methyl- & $0.027 \pm 0.001^{c}$ & $0.066 \pm 0.002^{\mathrm{a}}$ & $0.000 \pm 0.000^{d}$ & $0.045 \pm 0.003^{b}$ & $0.000 \pm 0.000^{d}$ & $0.000 \pm 0.000^{d}$ & $0.000 \pm 0.000^{d}$ & $0.000 \pm 0.000^{d}$ & $0.000 \pm 0.000^{d}$ & $0.000 \pm 0.000^{d}$ & $0.000 \pm 0.000^{d}$ & $0.000 \pm 0.000^{d}$ \\
\hline Ethyl isobutyrate & $0.000 \pm 0.000^{c}$ & $0.204 \pm 0.012^{\mathrm{a}}$ & $0.000 \pm 0.000^{c}$ & $0.073 \pm 0.004^{b}$ & $0.000 \pm 0.000^{c}$ & $0.000 \pm 0.000^{c}$ & $0.000 \pm 0.000^{c}$ & $0.000 \pm 0.000^{c}$ & $0.000 \pm 0.000^{c}$ & $0.000 \pm 0.000^{c}$ & $0.000 \pm 0.000^{c}$ & $0.000 \pm 0.000^{c}$ \\
\hline Isobutyl acetate & $0.020 \pm 0.000^{c d}$ & $0.000 \pm 0.000^{\mathrm{e}}$ & $0.037 \pm 0.006^{\mathrm{b}}$ & $0.010 \pm 0.009^{d}$ & $0.020 \pm 0.000^{\text {cd }}$ & $0.020 \pm 0.000^{c d}$ & $0.020 \pm 0.000^{\text {cd }}$ & $0.030 \pm 0.000^{c b}$ & $0.000 \pm 0.000^{\mathrm{e}}$ & $0.020 \pm 0.000^{c d}$ & $0.060 \pm 0.000^{\mathrm{a}}$ & $0.027 \pm 0.006^{\mathrm{bc}}$ \\
\hline Methyl isovalerate & $0.000 \pm 0.000 \mathrm{a}$ & $0.020 \pm 0.000 \mathrm{a}$ & $0.000 \pm 0.000 \mathrm{a}$ & $0.000 \pm 0.000 \mathrm{a}$ & $0.000 \pm 0.000 \mathrm{a}$ & $0.000 \pm 0.000 \mathrm{a}$ & $0.000 \pm 0.000 a$ & $0.000 \pm 0.000 \mathrm{a}$ & $0.000 \pm 0.000 \mathrm{a}$ & $0.000 \pm 0.000 \mathrm{a}$ & $0.000 \pm 0.000 \mathrm{a}$ & $0.000 \pm 0.000 \mathrm{a}$ \\
\hline 2.3-Butanediol & $0.000 \pm 0.000 \mathrm{~b}$ & $0.000 \pm 0.000 \mathrm{~b}$ & $0.000 \pm 0.000 \mathrm{~b}$ & $0.000 \pm 0.000 \mathrm{~b}$ & $0.020 \pm 0.000 \mathrm{a}$ & $0.020 \pm 0.000 \mathrm{a}$ & $0.000 \pm 0.000 \mathrm{~b}$ & $0.000 \pm 0.000 \mathrm{~b}$ & $0.023 \pm 0.006 \mathrm{a}$ & $0.027 \pm 0.006 \mathrm{a}$ & $0.030 \pm 0.010 \mathrm{a}$ & $0.020 \pm 0.000 \mathrm{a}$ \\
\hline
\end{tabular}

https://doi.org/10.32933/Actalnnovations.41.6• ISSN 2300-5599 • ㅇ 2021 RIC Pro-Akademia - CC BY 


\begin{tabular}{|c|c|c|c|c|c|c|c|c|c|c|c|c|}
\hline \multirow{3}{*}{ Compound } & \multicolumn{12}{|l|}{ Sample } \\
\hline & \multicolumn{6}{|c|}{ Group I - craft beers } & \multicolumn{6}{|c|}{ Group II - industrial beers } \\
\hline & A & B & c & D & E & $\mathbf{F}$ & G & H & 1 & $\mathrm{~J}$ & K & L \\
\hline Ethyl butanoate & $0.047 \pm 0.006^{b c}$ & $0.057 \pm 0.006^{b c}$ & $0.077 \pm 0.006^{a}$ & $0.053 \pm 0.006^{\mathrm{bc}}$ & $0.060 \pm 0.000^{b}$ & $0.043 \pm 0.006^{c}$ & $0.000 \pm 0.000^{d}$ & $0.047 \pm 0.006^{b c}$ & $0.057 \pm 0.006^{\mathrm{bc}}$ & $0.053 \pm 0.006^{\mathrm{bc}}$ & $0.077 \pm 0.006^{\mathrm{a}}$ & $0.060 \pm 0.000^{b}$ \\
\hline Furfural & $0.117 \pm 0.091^{\mathrm{a}}$ & $0.000 \pm 0.000^{b}$ & $0.057 \pm 0.015^{\mathrm{ab}}$ & $0.000 \pm 0.000^{b}$ & $0.000 \pm 0.000^{b}$ & $0.017 \pm 0.015^{b}$ & $0.000 \pm 0.000^{b}$ & $0.000 \pm 0.000^{b}$ & $0.000 \pm 0.000^{b}$ & $0.000 \pm 0.000^{b}$ & $0.000 \pm 0.000^{b}$ & $0.000 \pm 0.000^{b}$ \\
\hline Butanoic acid. 2-methyl-. ethyl ester & $0.000 \pm 0.000^{b}$ & $0.022 \pm 0.002^{\mathrm{a}}$ & $0.000 \pm 0.000^{b}$ & $0.000 \pm 0.000^{\mathrm{b}}$ & $0.000 \pm 0.000^{b}$ & $0.000 \pm 0.000^{b}$ & $0.000 \pm 0.000^{b}$ & $0.000 \pm 0.000^{b}$ & $0.000 \pm 0.000^{b}$ & $0.000 \pm 0.000^{b}$ & $0.000 \pm 0.000^{b}$ & $0.000 \pm 0.000^{b}$ \\
\hline Butanoic acid. 3-methyl-. ethyl ester & $0.000 \pm 0.000^{b}$ & $0.026 \pm 0.001^{\mathrm{a}}$ & $0.000 \pm 0.000^{b}$ & $0.000 \pm 0.000^{b}$ & $0.000 \pm 0.000^{b}$ & $0.000 \pm 0.000^{b}$ & $0.000 \pm 0.000^{b}$ & $0.000 \pm 0.000^{b}$ & $0.000 \pm 0.000^{b}$ & $0.000 \pm 0.000^{b}$ & $0.000 \pm 0.000^{b}$ & $0.000 \pm 0.000^{b}$ \\
\hline 1-Hexanol & $0.000 \pm 0.000^{b}$ & $0.045 \pm 0.002^{\mathrm{a}}$ & $0.000 \pm 0.000^{b}$ & $0.000 \pm 0.000^{b}$ & $0.000 \pm 0.000^{b}$ & $0.000 \pm 0.000^{b}$ & $0.000 \pm 0.000^{\mathrm{b}}$ & $0.000 \pm 0.000^{b}$ & $0.000 \pm 0.000^{b}$ & $0.000 \pm 0.000^{b}$ & $0.000 \pm 0.000^{b}$ & $0.000 \pm 0.000^{b}$ \\
\hline Isoamyl acetate & $0.840 \pm 0.092^{d}$ & $0.202 \pm 0.012^{f}$ & $1.479 \pm 0.165^{\mathrm{b}}$ & $0.521 \pm 0.031^{\mathrm{e}}$ & $0.723 \pm 0.031^{\mathrm{de}}$ & $0.893 \pm 0.065^{d}$ & $1.133 \pm 0.110^{c}$ & $1.583 \pm 0.098^{\mathrm{b}}$ & $0.862 \pm 0.075^{d}$ & $0.697 \pm 0.061^{\text {de }}$ & $2.677 \pm 0.053^{\mathrm{a}}$ & $1.239 \pm 0.031^{c}$ \\
\hline 2-Methylbutyl acetate & $0.067 \pm 0.006^{\mathrm{de}}$ & $0.000 \pm 0.000^{f}$ & $0.116 \pm 0.013^{b}$ & $0.051 \pm 0.004^{e}$ & $0.080 \pm 0.000^{c d}$ & $0.076 \pm 0.007^{d}$ & $0.107 \pm 0.012^{b}$ & $0.097 \pm 0.06^{b c}$ & $0.073 \pm 0.006^{d}$ & $0.077 \pm 0.006^{\text {cd }}$ & $0.233 \pm 0.009^{\mathrm{a}}$ & $0.108 \pm 0.002^{b}$ \\
\hline Isobutyl isobutyrate & $0.023 \pm 0.006^{b}$ & $0.079 \pm 0.005^{a}$ & $0.000 \pm 0.000^{c}$ & $0.081 \pm 0.006^{\mathrm{a}}$ & $0.000 \pm 0.000^{c}$ & $0.000 \pm 0.000^{c}$ & $0.000 \pm 0.000^{c}$ & $0.000 \pm 0.000^{c}$ & $0.000 \pm 0.000^{c}$ & $0.000 \pm 0.000^{c}$ & $0.000 \pm 0.000^{c}$ & $0.000 \pm 0.000^{c}$ \\
\hline Amyl propionate & $0.000 \pm 0.000^{c}$ & $0.040 \pm 0.003^{\mathrm{a}}$ & $0.000 \pm 0.000^{c}$ & $0.032 \pm 0.001^{b}$ & $0.000 \pm 0.000^{c}$ & $0.000 \pm 0.000^{c}$ & $0.000 \pm 0.000^{c}$ & $0.000 \pm 0.000^{c}$ & $0.000 \pm 0.000^{c}$ & $0.000 \pm 0.000^{c}$ & $0.000 \pm 0.000^{c}$ & $0.000 \pm 0.000^{c}$ \\
\hline$\beta$-Myrcene & $0.000 \pm 0.000^{b}$ & $0.564 \pm 0.014^{a}$ & $0.000 \pm 0.000^{b}$ & $0.000 \pm 0.000^{b}$ & $0.000 \pm 0.000^{b}$ & $0.000 \pm 0.000^{b}$ & $0.000 \pm 0.000^{b}$ & $0.000 \pm 0.000^{b}$ & $0.000 \pm 0.000^{b}$ & $0.000 \pm 0.000^{b}$ & $0.000 \pm 0.000^{b}$ & $0.000 \pm 0.000^{b}$ \\
\hline Ethyl caproate & $0.193 \pm 0.031^{\mathrm{bc}}$ & $0.000 \pm 0.000^{e}$ & $0.292 \pm 0.043^{\mathrm{a}}$ & $0.187 \pm 0.015^{b c}$ & $0.147 \pm 0.006^{\mathrm{cd}}$ & $0.187 \pm 0.012^{\mathrm{bc}}$ & $0.140 \pm 0.017^{\mathrm{cd}}$ & $0.117 \pm 0.006^{d}$ & $0.117 \pm 0.015^{\mathrm{d}}$ & $0.147 \pm 0.015^{\text {cd }}$ & $0.183 \pm 0.006^{\mathrm{bc}}$ & $0.203 \pm 0.006^{b}$ \\
\hline Butyl 2-methylbutyrate & $0.000 \pm 0.000^{\mathrm{a}}$ & $0.000 \pm 0.000^{\mathrm{a}}$ & $0.000 \pm 0.000^{\mathrm{a}}$ & $0.020 \pm 0.000^{\mathrm{a}}$ & $0.000 \pm 0.000^{\mathrm{a}}$ & $0.000 \pm 0.000^{\mathrm{a}}$ & $0.000 \pm 0.000^{\mathrm{a}}$ & $0.000 \pm 0.000^{\mathrm{a}}$ & $0.000 \pm 0.000^{\mathrm{a}}$ & $0.000 \pm 0.000^{\mathrm{a}}$ & $0.000 \pm 0.000^{\mathrm{a}}$ & $0.000 \pm 0.000^{\mathrm{a}}$ \\
\hline 1-Hexyl acetate & $0.000 \pm 0.000^{b}$ & $0.000 \pm 0.000^{b}$ & $0.023 \pm 0.003^{a}$ & $0.000 \pm 0.000^{b}$ & $0.000 \pm 0.000^{b}$ & $0.000 \pm 0.000^{\mathrm{b}}$ & $0.000 \pm 0.000^{b}$ & $0.000 \pm 0.000^{b}$ & $0.000 \pm 0.000^{b}$ & $0.000 \pm 0.000^{b}$ & $0.000 \pm 0.000^{b}$ & $0.000 \pm 0.000^{b}$ \\
\hline Isobutyric acid. isopentyl ester & $0.000 \pm 0.000^{c}$ & $0.108 \pm 0.007^{\mathrm{a}}$ & $0.000 \pm 0.000^{c}$ & $0.037 \pm 0.006^{b}$ & $0.000 \pm 0.000^{c}$ & $0.000 \pm 0.000^{c}$ & $0.000 \pm 0.000^{c}$ & $0.000 \pm 0.000^{c}$ & $0.000 \pm 0.000^{c}$ & $0.000 \pm 0.000^{c}$ & $0.000 \pm 0.000^{c}$ & $0.000 \pm 0.000^{c}$ \\
\hline 2-Methylbutyl isobutyrate & $0.030 \pm 0.000^{c}$ & $0.115 \pm 0.007^{b}$ & $0.000 \pm 0.000^{d}$ & $0.197 \pm 0.013^{a}$ & $0.000 \pm 0.000^{d}$ & $0.000 \pm 0.000^{d}$ & $0.000 \pm 0.000^{d}$ & $0.000 \pm 0.000^{d}$ & $0.000 \pm 0.000^{d}$ & $0.000 \pm 0.000^{d}$ & $0.000 \pm 0.000^{d}$ & $0.000 \pm 0.000^{d}$ \\
\hline $\begin{array}{l}\text { Hexanoic acid. 4-methylene-. methyl } \\
\text { ester }\end{array}$ & $0.037 \pm 0.006^{b}$ & $0.103 \pm 0.006^{a}$ & $0.027 \pm 0.006^{b}$ & $0.034 \pm 0.007^{b}$ & $0.000 \pm 0.000^{c}$ & $0.000 \pm 0.000^{c}$ & $0.000 \pm 0.000^{c}$ & $0.000 \pm 0.000^{c}$ & $0.000 \pm 0.000^{c}$ & $0.000 \pm 0.000^{c}$ & $0.000 \pm 0.000^{c}$ & $0.000 \pm 0.000^{c}$ \\
\hline Ethyl heptanoate & $0.000 \pm 0.000^{c}$ & $0.063 \pm 0.006^{a}$ & $0.000 \pm 0.000^{c}$ & $0.013 \pm 0.011^{b}$ & $0.000 \pm 0.000^{c}$ & $0.000 \pm 0.000^{c}$ & $0.000 \pm 0.000^{c}$ & $0.000 \pm 0.000^{c}$ & $0.000 \pm 0.000^{c}$ & $0.000 \pm 0.000^{c}$ & $0.000 \pm 0.000^{c}$ & $0.000 \pm 0.000^{c}$ \\
\hline 2-Nonanol & $0.000 \pm 0.000^{c}$ & $0.067 \pm 0.006^{\mathrm{a}}$ & $0.000 \pm 0.000^{c}$ & $0.012 \pm 0.011^{b}$ & $0.000 \pm 0.000^{c}$ & $0.000 \pm 0.000^{c}$ & $0.000 \pm 0.000^{c}$ & $0.000 \pm 0.000^{c}$ & $0.000 \pm 0.000^{c}$ & $0.000 \pm 0.000^{c}$ & $0.000 \pm 0.000^{c}$ & $0.000 \pm 0.000^{c}$ \\
\hline Linalool & $0.103 \pm 0.006^{c}$ & $0.647 \pm 0.040^{2}$ & $0.063 \pm 0.006^{d}$ & $0.332 \pm 0.021^{b}$ & $0.020 \pm 0.000^{e}$ & $0.027 \pm 0.006^{\text {de }}$ & $0.000 \pm 0.000^{\mathrm{e}}$ & $0.000 \pm 0.000^{\mathrm{e}}$ & $0.000 \pm 0.000^{e}$ & $0.000 \pm 0.000^{e}$ & $0.000 \pm 0.000^{e}$ & $0.000 \pm 0.000^{\mathrm{e}}$ \\
\hline 2-Phenylethanol & $0.112 \pm 0.010^{\mathrm{de}}$ & $0.196 \pm 0.004^{\mathrm{bc}}$ & $0.152 \pm 0.023^{\text {bcde }}$ & $0.100 \pm 0.007^{e}$ & $0.137 \pm 0.038^{\mathrm{de}}$ & $0.111 \pm 0.002^{\mathrm{de}}$ & $0.140 \pm 0.012^{\text {cde }}$ & $0.278 \pm 0.040^{\mathrm{a}}$ & $0.210 \pm 0.017^{b}$ & $0.147 \pm 0.015^{\text {cde }}$ & $0.167 \pm 0.015^{\text {bcd }}$ & $0.130 \pm 0.010^{\mathrm{de}}$ \\
\hline Octanoic acid (Caprylic acid) & $0.050 \pm 0.003^{\mathrm{a}}$ & $0.021 \pm 0.002^{\mathrm{d}}$ & $0.057 \pm 0.007^{\mathrm{a}}$ & $0.028 \pm 0.002^{\text {cd }}$ & $0.054 \pm 0.006^{\mathrm{a}}$ & $0.032 \pm 0.003^{\mathrm{bc}}$ & $0.021 \pm 0.002^{d}$ & $0.040 \pm 0.001^{b}$ & $0.000 \pm 0.000^{\mathrm{e}}$ & $0.000 \pm 0.000^{e}$ & $0.000 \pm 0.000^{\mathrm{e}}$ & $0.020 \pm 0.002^{d}$ \\
\hline Ethyl caprylate & $0.300 \pm 0.045 b$ & $0.606 \pm 0.030 \mathrm{a}$ & $0.289 \pm 0.046 \mathrm{~b}$ & $0.189 \pm 0.016 \mathrm{de}$ & $0.158 \pm 0.008$ def & $0.195 \pm 0.013 \mathrm{de}$ & $0.113 \pm 0.018 \mathrm{f}$ & $0.220 \pm 0.008 \mathrm{~cd}$ & $0.343 \pm 0.025 b$ & $0.133 \pm 0.012 \mathrm{ef}$ & $0.313 \pm 0.006 \mathrm{~b}$ & $0.343 \pm 0.009 \mathrm{~b}$ \\
\hline 2-Decanol & $0.000 \pm 0.000 \mathrm{~b}$ & $0.021 \pm 0.003 a$ & $0.000 \pm 0.000 \mathrm{~b}$ & $0.000 \pm 0.000 \mathrm{~b}$ & $0.000 \pm 0.000 \mathrm{~b}$ & $0.000 \pm 0.000 \mathrm{~b}$ & $0.000 \pm 0.000 \mathrm{~b}$ & $0.000 \pm 0.000 \mathrm{~b}$ & $0.000 \pm 0.000 \mathrm{~b}$ & $0.000 \pm 0.000 \mathrm{~b}$ & $0.000 \pm 0.000 \mathrm{~b}$ & $0.000 \pm 0.000 \mathrm{~b}$ \\
\hline$\alpha$-Terpineol & $0.000 \pm 0.000 \mathrm{~b}$ & $0.000 \pm 0.000 \mathrm{~b}$ & $0.000 \pm 0.000 \mathrm{~b}$ & $0.013 \pm 0.012 \mathrm{a}$ & $0.000 \pm 0.000 \mathrm{~b}$ & $0.000 \pm 0.000 \mathrm{~b}$ & $0.000 \pm 0.000 \mathrm{~b}$ & $0.000 \pm 0.000 \mathrm{~b}$ & $0.000 \pm 0.000 \mathrm{~b}$ & $0.000 \pm 0.000 \mathrm{~b}$ & $0.000 \pm 0.000 \mathrm{~b}$ & $0.000 \pm 0.000 \mathrm{~b}$ \\
\hline 5-Hydroxymethylfurfural & $0.057 \pm 0.006 \mathrm{ab}$ & $0.043 \pm 0.006 a b$ & $0.027 \pm 0.006 \mathrm{bcd}$ & $0.030 \pm 0.000 \mathrm{bcd}$ & $0.017 \pm 0.015 \mathrm{de}$ & $0.033 \pm 0.006 \mathrm{bcd}$ & $0.037 \pm 0.006 b c$ & $0.030 \pm 0.000 \mathrm{bcd}$ & $0.000 \pm 0.000 \mathrm{e}$ & $0.020 \pm 0.000 \mathrm{~cd}$ & $0.020 \pm 0.000 \mathrm{~cd}$ & $0.020 \pm 0.000 \mathrm{~cd}$ \\
\hline
\end{tabular}

https://doi.org/10.32933/Actalnnovations.41.6•ISSN 2300-5599 • ( 2021 RIC Pro-Akademia - CC BY 


\begin{tabular}{|c|c|c|c|c|c|c|c|c|c|c|c|c|}
\hline \multirow{3}{*}{ Compound } & \multicolumn{12}{|c|}{ Sample } \\
\hline & \multicolumn{6}{|c|}{ Group I - craft beers } & \multicolumn{6}{|c|}{ Group II - industrial beers } \\
\hline & A & B & c & D & E & $\mathbf{F}$ & G & H & 1 & $\mathrm{~J}$ & K & L \\
\hline Linalyl iso-valerate & $0.000 \pm 0.000^{b}$ & $0.063 \pm 0.006^{\mathrm{a}}$ & $0.000 \pm 0.000^{b}$ & $0.000 \pm 0.000^{b}$ & $0.000 \pm 0.000^{b}$ & $0.000 \pm 0.000^{b}$ & $0.000 \pm 0.000^{b}$ & $0.000 \pm 0.000^{\mathrm{b}}$ & $0.000 \pm 0.000^{b}$ & $0.000 \pm 0.000^{b}$ & $0.000 \pm 0.000^{b}$ & $0.000 \pm 0.000^{b}$ \\
\hline Phenethyl acetate & $0.033 \pm 0.006^{d}$ & $0.000 \pm 0.000^{e}$ & $0.063 \pm 0.006^{c}$ & $0.000 \pm 0.000^{e}$ & $0.033 \pm 0.006^{d}$ & $0.030 \pm 0.000^{d}$ & $0.063 \pm 0.006^{c}$ & $0.123 \pm 0.006^{b}$ & $0.060 \pm 0.000^{c}$ & $0.040 \pm 0.000^{d}$ & $0.143 \pm 0.006^{\mathrm{a}}$ & $0.070 \pm 0.000^{c}$ \\
\hline Ethyl pelargonate & $0.000 \pm 0.000^{b}$ & $0.034 \pm 0.008^{\mathrm{a}}$ & $0.000 \pm 0.000^{b}$ & $0.000 \pm 0.000^{b}$ & $0.000 \pm 0.000^{b}$ & $0.000 \pm 0.000^{\mathrm{b}}$ & $0.000 \pm 0.000^{b}$ & $0.000 \pm 0.000^{\mathrm{b}}$ & $0.000 \pm 0.000^{b}$ & $0.000 \pm 0.000^{b}$ & $0.000 \pm 0.000^{b}$ & $0.000 \pm 0.000^{b}$ \\
\hline 2-Undecanol & $0.000 \pm 0.000^{b}$ & $0.049 \pm 0.007^{a}$ & $0.000 \pm 0.000^{b}$ & $0.000 \pm 0.000^{b}$ & $0.000 \pm 0.000^{b}$ & $0.000 \pm 0.000^{b}$ & $0.000 \pm 0.000^{b}$ & $0.000 \pm 0.000^{b}$ & $0.000 \pm 0.000^{b}$ & $0.000 \pm 0.000^{b}$ & $0.000 \pm 0.000^{b}$ & $0.000 \pm 0.000^{b}$ \\
\hline Methyl geranate & $0.000 \pm 0.000^{b}$ & $0.126 \pm 0.011^{\mathrm{a}}$ & $0.000 \pm 0.000^{b}$ & $0.000 \pm 0.000^{\mathrm{b}}$ & $0.000 \pm 0.000^{\mathrm{b}}$ & $0.000 \pm 0.000^{\mathrm{b}}$ & $0.000 \pm 0.000^{b}$ & $0.000 \pm 0.000^{b}$ & $0.000 \pm 0.000^{\mathrm{b}}$ & $0.000 \pm 0.000^{b}$ & $0.000 \pm 0.000^{\mathrm{b}}$ & $0.000 \pm 0.000^{b}$ \\
\hline Capric acid (Decanoic acid) & $0.020 \pm 0.000^{\mathrm{a}}$ & $0.000 \pm 0.000^{\mathrm{a}}$ & $0.000 \pm 0.000^{\mathrm{a}}$ & $0.000 \pm 0.000^{\mathrm{a}}$ & $0.000 \pm 0.000^{\mathrm{a}}$ & $0.000 \pm 0.000^{\mathrm{a}}$ & $0.000 \pm 0.000^{\mathrm{a}}$ & $0.000 \pm 0.000^{\mathrm{a}}$ & $0.000 \pm 0.000^{2}$ & $0.000 \pm 0.000^{\mathrm{a}}$ & $0.000 \pm 0.000^{\mathrm{a}}$ & $0.000 \pm 0.000^{\mathrm{a}}$ \\
\hline 4-Decenoic acid. ethyl ester. (Z) & $0.000 \pm 0.000^{b}$ & $0.027 \pm 0.006^{\mathrm{a}}$ & $0.000 \pm 0.000^{b}$ & $0.000 \pm 0.000^{b}$ & $0.000 \pm 0.000^{b}$ & $0.000 \pm 0.000^{b}$ & $0.000 \pm 0.000^{b}$ & $0.000 \pm 0.000^{b}$ & $0.000 \pm 0.000^{b}$ & $0.000 \pm 0.000^{b}$ & $0.000 \pm 0.000^{b}$ & $0.000 \pm 0.000^{b}$ \\
\hline Ethyl caprate & $0.073 \pm 0.006^{c}$ & $0.137 \pm 0.015^{b}$ & $0.047 \pm 0.012^{\text {cde }}$ & $0.020 \pm 0.000^{\mathrm{e}}$ & $0.020 \pm 0.000^{e f}$ & $0.043 \pm 0.006^{\mathrm{de}}$ & $0.000 \pm 0.000^{f}$ & $0.030 \pm 0.000^{\text {de }}$ & $0.197 \pm 0.023^{a}$ & $0.047 \pm 0.006^{\text {cde }}$ & $0.033 \pm 0.006^{\text {de }}$ & $0.057 \pm 0.006^{\mathrm{cd}}$ \\
\hline Humulene & $0.000 \pm 0.000^{b}$ & $0.027 \pm 0.006^{\mathrm{a}}$ & $0.000 \pm 0.000^{\mathrm{b}}$ & $0.000 \pm 0.000^{b}$ & $0.000 \pm 0.000^{b}$ & $0.000 \pm 0.000^{b}$ & $0.000 \pm 0.000^{b}$ & $0.000 \pm 0.000^{b}$ & $0.000 \pm 0.000^{b}$ & $0.000 \pm 0.000^{\mathrm{b}}$ & $0.000 \pm 0.000^{\mathrm{b}}$ & $0.000 \pm 0.000^{\mathrm{b}}$ \\
\hline
\end{tabular}

Values marked by different letters (a-i) within the same line differ significantly with a $p$ value $\leq 0.05$

Apart from ethanol that constituted the major volatile compounds, in all 12 samples the largest share in the profile belonged to two esters: ethyl acetate (2.63 - 5.06\%) and isoamyl acetate $(0.20-2.68 \%)$ as well as two alcohols: 3-methyl-1-butanol $(3.94-6.41 \%)$ and 2-methyl-1-butanol $(1.62-2.45 \%)$, which is also in accordance with findings reported in the literature $[23,39]$. Volatile esters give the beer fruity character, so in generic terms our results demonstrated that craft beers might be characterised by fruity flavours to a higher degree than industrial beers. Nevertheless, it should be highlighted that the industrial beers showed a greater presence of isoamyl acetate. This volatile ester is characterised by a "banana flavour". The sample K of industrial beer featured also significantly higher ethyl acetate content in comparison to other beers $(\mathrm{P}<0.05)$ (Table 3 on the basis of results received from [30]). In the case of that specific sample (K), it may be assumed that such results may have stemmed from the addition of sugar syrups being added to wort when high gravity brewing technology is implemented (information about the addition of sugar syrups was included on the label of the beer marked with $\mathrm{K}$ letter). It has previously been shown that high-gravity brewing $\left(>16^{\circ} \mathrm{Plato}\right)$ is associated with disproportionate higher levels of esters, particularly ethyl acetate and isoamyl acetate [39]. According to the literature, many commercial brewing companies and only some large craft breweries use HGB [40]. The results of present study also share a few of similarities with Giannetti's et. al. (2019) [5] and Giannetti's et. al. (2018) [11] findings in terms of other esters being detected in craft and industrial beers. Similarly, 2-methylbutyl isobutyrate was not detected in any of the industrial beers studied, whereas it was detected in 3 out of 6 craft beers (samples A, B and D). Isobutyl isobutyrate was also detected only in those three samples of craft beers. There is evidence to support the hypothesis that those specific esters come from unique hop cultivars and contribute with a green apple, apricot-like flavour [41,42]. This implies that craft breweries use some special hop varieties, apparently not being used in industrial breweries. With respect to hop-derived volatile compounds attention should be also paid to terpenes introducing woody and spicy flavours. These kinds of volatiles (e.g. the terpene alcohol - linalool - forming the pleasant citrus and fruity notes [43])

https://doi.org/10.32933/Actalnnovations.41.6•ISSN 2300-5599• ㅇ 2021 RIC Pro-Akademia - CC BY 
was only detected in craft beers. Giannetti et. al. (2019) [5] have also found that phenethyl acetate (characterised by a rose-like flavour) is more concentrated in industrial beers, which is in good agreement with our findings (table 3). Also higher alcohols play a crucial role in the flavour of beer. Of particular importance is 2phenylethanol characterised as possessing „rose flavour" [44]. In line with previous studies [5], the highest content of 2-phenylethanol was in the industrial beers (sample $\mathrm{H}$ and I), which made them have a better fragrance, taste and rose like aroma.

Giannetti et. al. (2019) [5] noted that industrial beers featured a higher acids content. Our results do not seem to confirm their observation, since carboxylic acids identified, i.e. acetic acid, octanoic acid and decanoic acid were either present at significantly higher levels in the craft beers $(P<0.05)$ (acetic and octanoic acid - samples $A, D, F)$ or were not detected in the industrial beers whatsoever (decanoic acid) (Table 3). The control of both acetic acid and octanoic acid production during brewing is crucial since at concentrations above their taste thresholds (200 and 5 ppm for Pilsener-style respectively) they impart off-flavour [45-47]. Acetic acid contributes with vinegary odour, whereas octanoic acid with rancid notes [47]. The level of carboxylic acids in beer is mostly contingent on the yeast strain, however, it was also shown that beers obtained with a low level of wort saturation with oxygen were characterised by exceeding contents of octanoic acid and consequently by rancid flavours [46]. Beer volatiles from the group of carbonyl compounds are ketones and aldehydes. According to the literature, some specific compounds such as furfural or 2,3-butanedione (diacetyl) may be considered important markers of beer flavour deterioration [11,17]. Furfural is formed during beer ageing by Maillard reaction [11,17]. It was found that the industrial beers did not contain furfural, whereas 3 out of 6 craft beers contained that substance (sample A, C, F). On the other hand, 2,3-butanedione was not detected in any sample of the beer analysed in the study. One of the main purposes of the study was to investigate whether the manufacturing scale affect dimethyl sulphide (DMS) content in the finished product. DMS was the only sulphur compound detected in the beers. Through the evaluation of average concentration, expressed in $\mu \mathrm{g} / \mathrm{l}$, of dimethyl sulphide, it is clear that the craft beers are characterised by a significantly higher content of DMS than industrial beers $(P<0.05)$ (Table 1 and 3 , Figure 2f). DMS was not detected in 4 out of 6 industrial beers, whereas the volatile compounds profile of all the craft beers included the presence of DMS. Additionally, in the case of the samples C (136.3 $\mathrm{gg} / \mathrm{l})$ and D (137.5 $\mu \mathrm{g} / \mathrm{l})$ the concentrations of DMS exceeded the limit values $(100 \mu \mathrm{g} / \mathrm{l})$ established for lager beer [20,21]. Therefore, it may be assumed that DMS adversely affect the aroma of the beers C and D and may lead to undesirable flavour impressions, while drinking them by consumers. DMS concentration in beer is dependent on the wort boiling technology (vigour of the boil) as well as on the wort aeration level prior to fermentation. 
Table 4. Comparison of obtained LRI values with literature data.

\begin{tabular}{|c|c|c|c|c|}
\hline Compound & $\mathbf{R T}$ average & LRI $\mathbf{I}_{\text {calc }}$ & $\mathbf{L R I _ { \text { lit } }}$ & Literature \\
\hline Acetaldehyde & 4.73 & & & \\
\hline Ethanol & 5.41 & & & \\
\hline Acetone & 5.80 & & & \\
\hline 2-propanol & 5.89 & & & \\
\hline 2-Nitroethanol & 5.90 & & & \\
\hline Ethyl formate & 6.11 & & & \\
\hline DMS & 6.21 & & & \\
\hline 1-propanol & 6.77 & & & \\
\hline Acetic acid & 7.24 & & & \\
\hline Ethyl acetate & 7.77 & & & \\
\hline Isobutanol & 8.05 & & & \\
\hline 1-butanol & 8.79 & & & \\
\hline 3-Methyl-2-butanone & 8.78 & & & \\
\hline Methyl isobutyrate & 9.27 & & & \\
\hline Ethyl propionate & 9.79 & 710 & 696 & {$[25]$} \\
\hline Propyl acetate & 9.85 & 713 & & \\
\hline 1-Butanol. 3-methyl- & 10.32 & 735 & 718,747 & {$[25,26]$} \\
\hline 1-Butanol. 2-methyl- & 10.41 & 739 & $728,744,744$ & \begin{tabular}{|l|}
{$[25,27,28]$} \\
\end{tabular} \\
\hline 2-Pentanone. 4-methyl- & 10.49 & 743 & & \\
\hline Ethyl isobutyrate & 10.82 & 759 & 756 & {$[27]$} \\
\hline Isobutyl acetate & 11.14 & 774 & 776 & {$[27]$} \\
\hline Methyl isovalerate & 11.23 & 778 & & \\
\hline 2.3-Butanediol & 11.28 & 780 & 796 & {$[25]$} \\
\hline Ethyl butanoate & 11.70 & 800 & 806,800 & {$[25,27]$} \\
\hline Furfural & 12.61 & 842 & 829,845 & {$[27,29]$} \\
\hline Butanoic acid. 2-methyl-. ethyl ester & 12.78 & 850 & 846 & {$[27]$} \\
\hline Butanoic acid. 3-methyl-. ethyl ester & 12.83 & 852 & 854 & {$[27]$} \\
\hline 1-Hexanol & 13.17 & 868 & 880,880 & {$[25,27]$} \\
\hline Isoamyl acetate & 13.33 & 876 & 876,871 & {$[27,29]$} \\
\hline 2-Methylbutyl acetate & 13.39 & 878 & 877,873 & {$[19,29]$} \\
\hline Isobutyl isobutyrate & 14.17 & 914 & & \\
\hline Amyl propionate & 15.43 & 970 & & \\
\hline$\beta$-Myrcene & 16.00 & 996 & 988,991 & {$[19,29]$} \\
\hline Ethyl caproate & 16.01 & 997 & $996,1000,996,1000,1003$ & {$[25-29]$} \\
\hline Butyl 2-methylbutyrate & 16.18 & 1004 & & \\
\hline 1-Hexyl acetate & 16.31 & 1010 & 1006 & {$[25]$} \\
\hline Isobutyric acid. isopentyl ester & 16.35 & 1012 & 1014 & [29] \\
\hline 2-Methylbutyl isobutyrate & 16.45 & 1017 & & \\
\hline Hexanoic acid. 4-methylene-. methyl ester & 16.77 & 1031 & & \\
\hline Ethyl heptanoate & 18.19 & 1096 & $1095,1097,1097,1101$ & {$[25,27-29]$} \\
\hline 2-Nonanol & 18.32 & 1102 & $1107,1098,1102,1103$ & {$[25,27-29]$} \\
\hline Linalool & 18.44 & 1108 & & \\
\hline 2-Phenylethanol & 19.10 & 1138 & $1119,1135,1118,1112,1113$ & {$[25-29]$} \\
\hline octanoic acid (Caprylic acid) & 19.48 & 1156 & $1169,1179,1192,1180$ & \begin{tabular}{|ll}
$26-29]$ \\
\end{tabular} \\
\hline Ethyl caprylate & 20.34 & 1196 & $1196,1193,1198,1198,1202$ & [25-29] \\
\hline 2-Decanol & 20.49 & 1203 & 1211 & {$[29]$} \\
\hline$\alpha$-Terpineol & 20.84 & 1220 & 1195 & {$[25]$} \\
\hline 5-Hydroxymethylfurfural & 21.21 & 1238 & & \\
\hline Linalyl iso-valerate & 21.75 & 1264 & & \\
\hline Phenethyl acetate & 22.02 & 1277 & $1260,1260,1255,1257$ & {$[25,27-29]$} \\
\hline Ethyl pelargonate & 22.41 & 1296 & $1295,1297,1296,1297$ & {$[25,27-29]$} \\
\hline 2-Undecanol & 22.60 & 1305 & 1309 & {$[25]$} \\
\hline Methyl geranate & 23.17 & 1334 & 1320 & {$[29]$} \\
\hline Capric acid (Decanoic acid) & 23.61 & 1356 & $1387,1382,1373,1366$ & [25-28] \\
\hline 4-Decenoic acid. ethyl ester. (Z)- & 24.16 & 1384 & & \\
\hline Ethyl caprate & 24.39 & 1396 & $1396,1391,1398,1395,1398$ & {$[25-29]$} \\
\hline Humulene & 26.62 & 1515 & 1463,1454 & {$[26,29]$} \\
\hline
\end{tabular}




\section{Impact}

The results might have significant implications for improving the chemical-technical quality control system in a craft brewery whereby it would be possible to provide an average consumer with a somewhat more standardised final product in terms of beer flavour and physicochemical attributes.

The Introduction of gas chromatography techniques in a brewery for the purpose of controlling the quality of wort and beer might have a positive impact on the efficiency of the overall brewing process, owing to easier evaluation and quicker identification of the reasons for obtaining an undesirable beer volatile profile and subsequent modification of brewing technology (regulation and proper setting of specific technological parameters).

\section{Conclusions}

The conducted research has shown that the scale of production significantly affects the profile of volatile compounds and physicochemical parameters of the pale Pilsener-style lager beers. Therefore, it is concluded that there is a clear need to control the quality of Pilsener-style beers available on the market, produced both on an industrial and a craft scale.

Headspace gas chromatography coupled to mass spectrometry (HS/GC-MS) is a powerful and accurate diagnostic tool for determination of beer flavour attributes, including detection of potential off-flavours.

\section{Conflict of interest}

There are no conflicts to declare.

\section{Acknowledgements}

The study was carried out as part of a research project "Design and Implementation of non-alcoholic gruit beer" (POIR.04.01.04-00-0099/19), financed by The National Centre for Research and Development. We would also like to thank the entire RIC Pro-Akademia team for their valuable guidance and support during the preparation of this article.

\section{References}

[1] A.O. Olaniran, L. Hiralal, M.P. Mokoena, B. Pillay, Flavour-active volatile compounds in beer: production, regulation and control, J. Inst. Brew. 123 (2017) 13-23. https://doi.org/10.1002/jib.389.

[2] K. Lutosławski, R. Olędzki, Ł. Kiebel, Jakość sensoryczna piw jasnych górnej fermentacji produkcji domowej i komercyjnej, Pr. Nauk. Uniw. Ekon. We Wrocławiu. (2018) 77-89. https://doi.org/10.15611/pn.2018.542.06.

[3] Polskie Stowarzyszenie Browarów Rzemieślniczych, Raport z działalności browarów zrzeszonych w polskim stowarzyszeniu browarów rzemiślniczych w 2019 roku, 2020. https://psbr.eu/resources/PSBR_Raport6.7.pdf.

[4] B. Wojtyra, Ł. Grudzień, Rozwój przemysłu piwowarskiego w Polsce w okresie tzw. piwnej rewolucji w latach 2011-2016, Stud. Ind. Geogr. Comm. Polish Geogr. Soc. 31 (2017) 52-67. https://doi.org/10.24917/20801653.311.4.

[5] V. Giannetti, M. Boccacci Mariani, P. Torrelli, F. Marini, Flavour component analysis by HS-SPME/GC-MS and chemometric modeling to characterize Pilsner-style Lager craft beers, Microchem. J. 149 (2019). https://doi.org/10.1016/j.microc.2019.103991.

[6] W. Maszkowski, M. Wysokiński, Distribution of beer in micro and small breweries in Poland, Ann. Polish Assoc. Agric. Agribus. Econ. 19 (2018) 159-164. https://doi.org/10.5604/01.3001.0010.7922.

[7] M. Jesús Callejo, W. Tesfaye, M. Carmen González, A. Morata, Craft beers: current situation and future trends, in: New Adv. Ferment. Process., IntechOpen, 2020. https://doi.org/10.5772/intechopen.90006.

[8] A. Baiano, Craft beer: an overview, Compr. Rev. Food Sci. Food Saf. 20 (2021) 1829-1856. https://doi.org/10.1111/1541-4337.12693.

[9] T. Podeszwa, Craft brewing - the grassroots activity of micro-manufacturers as a stimulant for market development and self-improvement in the brewing industry, Acta Innov. 15 (2015) 51-56.

[10] Polskie Stowarzyszenie Browarów Rzemieślniczych, Browary rzemieślnicze - definicja, (2021). https://psbr.eu/.

[11] V. Giannetti, M. Boccacci Mariani, P. Torrelli, Characterization of craft beer through flavour component analysis by GC-MS and multivariate statistical tools, 2018. 
https://iris.uniroma1.it/retrieve/handle/11573/1082939/629981/Giannetti et al_Beers.pdf.

[12] R. Manelius, Beer flavor component analyses for small breweries, Turku University of Applied Sciences, 2017.

https://www.theseus.fi/bitstream/handle/10024/133536/Manelius_Robin.pdf?sequence=4\&isAllowed $=\mathrm{y}$.

[13] K. Kucharczyk, T. Tuszyński, The effect of temperature on fermentation and beer volatiles at an industrial scale, J. Inst. Brew. 124 (2018) 230-235. https://doi.org/10.1002/jib.491.

[14] Z.H. Mohammad, C.C. Ray, J.A. Neal, G. Cordua, A. Corsi, S.A. Sirsat, Implications of temperature abuse on unpasteurized beer quality using organoleptic and chemical analyses, Foods. 9 (2020) 1032. https://doi.org/10.3390/foods9081032.

[15] A. Siwek, M.A. Stachelska, M. Dziadkowska, P. Karpiński, M.W. Obiedziński, Związki lotne w piwach wyprodukowanych z udziałem ryżu, Przem. Ferment. I Owocowo-Warzywny. 1 (2016) 10-12. https://doi.org/10.15199/64.2016.7-8.1.

[16] C. Boulton, Encyclopedia of brewing, John Wiley \& Sons, Ltd, Oxford, UK, 2013. https://doi.org/10.1002/9781118598115.

[17] S. Rossi, V. Sileoni, G. Perretti, O. Marconi, Characterization of the volatile profiles of beer using headspace solid-phase microextraction and gas chromatography-mass spectrometry, J. Sci. Food Agric. 94 (2014) 919-928. https://doi.org/10.1002/jsfa.6336.

[18] L. Cao, G. Zhou, P. Guo, Y. Li, Influence of pasteurising intensity on beer flavour stability, J. Inst. Brew. 117 (2011) 587-592. https://doi.org/10.1002/j.2050-0416.2011.tb00508.x.

[19] C. Martins, A. Almeida, S.M. Rocha, Recent advances and challenges for beer volatile characterization based on gas chromatographic techniques, in: Atta-ur-Rahman, S.A. Ozkan, R. Ahmed (Eds.), Recent Adv. Anal. Tech., Bentham Science Publishers, 2017: pp. 141-199. https://doi.org/10.2174/97816810844731170101.

[20] K. Kucharczyk, K. Zyła, T. Tuszyński, Simultaneous optimization of acetaldehyde and DMS concentrations for better sensory quality of beer fermented on an industrial scale, Foods. 9 (2020) 1043. https://doi.org/10.3390/foods9081043.

[21] M. Baldus, P. Kreuschner, M. Hutzler, F.J. Methner, On the behaviour of dimethyl sulfoxide in the brewing process and its role as dimethyl sulfide precursor in beer, Brewingscience. 71 (2018). https://doi.org/10.23763/BrSc18-01baldus.

[22] K. Kucharczyk, T. Tuszyński, Obecność diacetylu i 2,3-pentanodionu w piwie, Zywność. Nauk. Technol. Jakość. 24 (2017) 17-26. https://doi.org/10.15193/zntj/2017/113/207.

[23] A. Siwek, M.A. Stachelska, A. Ekielski, T. Zelazinski, E. Sobolewska, P. Karpinski, J. Rozmierska, M.W. Obiedzinski, Analiza profilu związków lotnych w piwach wyprodukowanych z udziałem grysu kukurydzianego, Przem. Ferment. I Owocowo-Warzywny. 1 (2016) 22-24. https://doi.org/10.15199/64.2016.3.5.

[24] H.E. Anderson, I.C. Santos, Z.L. Hildenbrand, K.A. Schug, A review of the analytical methods used for beer ingredient and finished product analysis and quality control, Anal. Chim. Acta. 1085 (2019). https://doi.org/10.1016/j.aca.2019.07.061.

[25] C. Martins, T. Brandão, A. Almeida, S.M. Rocha, Enlarging Knowledge on Lager Beer Volatile Metabolites Using Multidimensional Gas Chromatography, Foods. 9 (2020). https://doi.org/10.3390/foods9091276.

[26] X. Ji, Comparative investigation of volatile components and bioactive compounds in beers by multivariate analysis, Flavour Fragr. J. 36 (2021). https://doi.org/10.1002/ffj.3649.

[27] K. Thompson Witrick, S. Duncan, K. Hurley, S. O'Keefe, Acid and volatiles of commercially-available lambic beers, Beverages. 3 (2017). https://doi.org/10.3390/beverages3040051.

[28] K. Witrick, E.R. Pitts, S.F. O'Keefe, Analysis of lambic beer volatiles during aging using gas chromatography-mass spectrometry (GCMS) and gas chromatography-olfactometry (GCO), Beverages. 6 (2020). https://doi.org/10.3390/beverages6020031.

[29] E. Trovato, A. Arigò, F. Vento, G. Micalizzi, P. Dugo, L. Mondello, Influence of citrus flavor addition in brewing process: characterization of the volatile and non-volatile profile to prevent frauds and adulterations, Separations. 8 (2021). https://doi.org/10.3390/separations8020018.

[30] TIBCO Software Inc., Statistica, (2017).

[31] M.G. Amato, Sensory evaluation, in: O. Garrett (Ed.), Oxford Companion to Beer, Oxford University Press, 2011. https://doi.org/10.1093/acref/9780195367133.001.0001.

[32] G. Van Doorn, J. Timora, S. Watson, C. Moore, C. Spence, The visual appearance of beer: a review concerning visually-determined expectations and their consequences for perception, Food Res. Int. 126 
(2019). https://doi.org/10.1016/j.foodres.2019.108661.

[33] A. Poreda, A. Czarnik, M. Zdaniewicz, M. Jakubowski, P. Antkiewicz, Corn grist adjunct - application and influence on the brewing process and beer quality, J. Inst. Brew. 120 (2014) 77-81. https://doi.org/10.1002/jib.115.

[34] V. Psota, Z. Skulilová, J. Hartmann, The effect of the barley variety, location and year crop on the haze of congress wort, Czech J. Food Sci. 27 (2009) 158-164. https://doi.org/10.17221/156/2008-CJFS.

[35] P.H. Chlup, real degree of fermentation (RDF), in: O. Garrett (Ed.), Oxford Companion to Beer, Oxford University Press, 2011. https://doi.org/10.1093/acref/9780195367133.001.0001.

[36] A. Andrade, E. Lima, L. Meirelles, Avaliação da rotulagem e qualidade de diferentes marcas de cerveja tipo pilsen, 2016. https://www.researchgate.net/publication/329100815.

[37] Rozporządzenie Parlamentu Europejskiego i Rady (UE) nr 1169/2011 z dnia 25 października 2011 r. w sprawie przekazywania konsumentom informacji na temat żywności, zmiany rozporządzeń Parlamentu Europejskiego i Rady (WE) nr 1924/2006 i (WE) nr 1925/2006, 2011.

[38] L.M. Tozetto, R.F. Do Nascimento, M.H. de Oliveira, J. Van Beik, M.H.G. Canteri, Production and physicochemical characterization of craft beer with ginger (Zingiber officinale), Food Sci. Technol. 39 (2019) 962-970. https://doi.org/10.1590/fst.16518.

[39] M.P. Piddocke, S. Kreisz, H.P. Heldt-Hansen, K.F. Nielsen, L. Olsson, Physiological characterization of brewer's yeast in high-gravity beer fermentations with glucose or maltose syrups as adjuncts, Appl. Microbiol. Biotechnol. 84 (2009). https://doi.org/10.1007/s00253-009-1930-y.

[40] K. Villa, high gravity brewing, in: O. Garrett (Ed.), Oxford Companion to Beer, Oxford University Press, 2011. https://doi.org/10.1093/acref/9780195367133.001.0001.

[41] K. Takoi, M. Degueil, S. Shinkaruk, C. ThiBon, T. Kurihara, K. Toyoshima, K. Ito, B. Bennetau, D. Dubourdieu, T. Tominaga, Specific flavor compounds derived from nelson sauvin hop and synergy $\begin{array}{lllll}\text { of these compounds, } & \text { BrewingScience. } & 62 & \text { (2009) }\end{array}$ https://www.researchgate.net/publication/261476079.

[42] K. Takoi, Y. Itoga, K. Koie, J. Takayanagi, T. Kaneko, T. Watanabe, I. Matsumoto, M. Nomura, Behaviour of hop-derived branched-chain esters during fermentation and unique characteristics of Huell Melon and Ekuanot (HBC366) Hops, BrewingScience. 71 (2018) 100-109. https://doi.org/10.23763/BrSc18-14takoi.

[43] T. Podeszwa, J. Harasym, New methods of hopping (dryhopping) and their impact on sensory properties of beer, Acta Innov. 79 (2016) 79-86.

[44] C. Li, G. Dong, M. Bian, X. Liu, J. Gong, J. Hao, W. Wang, K. Li, W. Ou, T. Xia, Brewing rich 2-phenylethanol beer from cassava and its producing metabolisms in yeast, J. Sci. Food Agric. 101 (2021) 4050-4058. https://doi.org/10.1002/jsfa.11040.

[45] Y. Zhang, S. Jia, W. Zhang, Predicting acetic acid content in the final beer using neural networks and support vector machine, J. Inst. Brew. 118 (2012) 361-367. https://doi.org/10.1002/jib.50.

[46] S. Engan, H. Bryggeri, Organoleptic threshold values of some organic acids in beer, J. Inst. Brew. 80 (1974) 162-163. https://onlinelibrary.wiley.com/doi/pdf/10.1002/j.2050-0416.1974.tb03598.x.

[47] K. Shale, J. Mukamugema, R.J. Lues, P. Venter, K.K. Mokoena, Characterisation of selected volatile organic compounds in Rwandan indigenous beer 'Urwagwa' by dynamic headspace gas chromatography-mass spectrometry, African J. Biotechnol. 12 (2013) 2990-2996. https://doi.org/10.5897/AJB12.1173. 